Article

\title{
Evolution of Ore-Forming Fluids and Gold Deposition of the Sanakham Lode Gold Deposit, SW Laos: Constrains from Fluid Inclusions Study
}

\author{
Shusheng Liu ${ }^{1,2}$, Linnan Guo ${ }^{2, *}$, Jun Ding ${ }^{2}$, Lin Hou ${ }^{2}$, Siwei Xu ${ }^{2}$, Meifeng Shi ${ }^{2}$, Huimin Liang ${ }^{2}$, Fei Nie ${ }^{3}$ \\ and Xiaoyu Cui ${ }^{4}$ \\ 1 College of Earth Sciences, Chengdu University of Technology, Chengdu 610059, China; cdlshusheng@163.com \\ 2 Chengdu Center, China Geological Survey, Chengdu 610081, China; 13980689100@163.com (J.D.); \\ houlin_aaron@163.com (L.H.); xswxswxsw@163.com (S.X.); shimeifeng-1204@163.com (M.S.); \\ lianghm_cugb@126.com (H.L.) \\ 3 Research Center of Applied Geology, China Geological Survey, Chengdu 610036, China; niefei_cugb@163.com \\ 4 Sichuan Zhuyu Investment Co., Ltd., Chengdu 610042, China; xy92159168@163.com \\ * Correspondence: linnanguo@163.com; Tel.: +86-028-82321057
}

check for

updates

Citation: Liu, S.; Guo, L.; Ding, J.;

Hou, L.; Xu, S.; Shi, M.; Liang, H.;

Nie, F.; Cui, X. Evolution of

Ore-Forming Fluids and Gold

Deposition of the Sanakham Lode

Gold Deposit, SW Laos: Constrains

from Fluid Inclusions Study. Minerals

2022, 12, 259. https://doi.org/

$10.3390 / \min 12020259$

Academic Editors: Kunfeng Qiu and

Galina Palyanova

Received: 8 December 2021

Accepted: 30 January 2022

Published: 17 February 2022

Publisher's Note: MDPI stays neutral with regard to jurisdictional claims in published maps and institutional affiliations.

Copyright: (c) 2022 by the authors. Licensee MDPI, Basel, Switzerland. This article is an open access article distributed under the terms and conditions of the Creative Commons Attribution (CC BY) license (https:// creativecommons.org/licenses/by/ $4.0 /)$.

\begin{abstract}
The Sanakham gold deposit is a newly discovered gold deposit in the Luang Prabang (Laos)-Loei (Thailand) metallogenic belt. It consists of a series of auriferous quartz-sulfide veins, which is distinguished from the regional known porphyry-related skarn and epithermal gold deposits. There are four mineralization stages identified in Sanakham, with native gold grains mainly occurring in stages II and III. Evolution of ore-forming fluids and gold deposition mechanisms in Sanakham are discussed based on fluid inclusion petrography, microthermometry, and Laser Raman spectroscopy. The original ore-forming fluids belong to a medium-high temperature $\left(>345^{\circ} \mathrm{C}\right) \mathrm{CH}_{4}$-rich $\mathrm{CH}_{4}-\mathrm{CO}_{2}-$ $\mathrm{NaCl}-\mathrm{H}_{2} \mathrm{O}$ system. In stages II and III, the ore fluids evolve into a $\mathrm{NaCl}-\mathrm{H}_{2} \mathrm{O}-\mathrm{CO}_{2} \pm \mathrm{CH}_{4}$ system characterized by medium temperature $\left(\sim 300^{\circ} \mathrm{C}\right)$, medium salinity $(\sim 10 \mathrm{wt} \% \mathrm{NaCl}$ eq. $)$, and $\mathrm{CO}_{2}$-rich $(\sim 10 \% \mathrm{~mol})$. They might finally evolve into a $\mathrm{NaCl}-\mathrm{H}_{2} \mathrm{O}$ system with temperature decreasing and salinity increasing in stage IV. Two fluid immiscibility processes occurred in stages II and III, which created high- $\mathrm{CH}_{4}$ \& low- $\mathrm{CO}_{2}$ and low- $\mathrm{CH}_{4}$ \& high- $\mathrm{CO}_{2}$ end-members, and $\mathrm{CO}_{2}$-poor and $\mathrm{CO}_{2}$-rich endmembers, respectively. Gold-deposition events are suggested to be associated with the fluid immiscibility processes, with $\mathrm{P}-\mathrm{T}$ conditions and depth of $236-65 \mathrm{MPa}, 337-272{ }^{\circ} \mathrm{C}$, and $8.7-6.5 \mathrm{~km}$, respectively.
\end{abstract}

Keywords: fluid inclusion; $\mathrm{CH}_{4}$ - and $\mathrm{CO}_{2}$-rich ore fluids; fluid immiscibility; gold deposition; Sanakham gold deposit; Laos

\section{Introduction}

The mainland of Southeast Asia consists of a series of continental blocks or terranes together with related sutures and volcanic arcs (Figure 1a). It is endowed with a diversity of mineral resources distributed in several important metallogenetic belts, such as the Truong Son Fe-Cu-Au-W-Sn belt, Vientiane-Kon Tum K-Al-Cu-Au belt, Da Lat Au-Fe-Cu belt, Gulf of Thailand-East Malaysia Au-Sb-Cu belt, and the Luang Prabang-Loei Cu-Au-Ag belt [1]. The Luang Prabang (Laos)-Loei (Thailand) metallogenic belt lies along the western periphery of the Indochina Block, to the east of Changning-Menglian-Chieng Mai Suture zone (Figure 1a). The belt, formed during the subduction-accretionary orogeny of the Paleo-Tethys Ocean and the subsequent collisional orogeny between the Sibumasu Block and the Indochina Block, is traditionally recognized as a metallogenic belt dominated by porphyry-related skarn and epithermal deposits [2,3] (Figure 1b). 


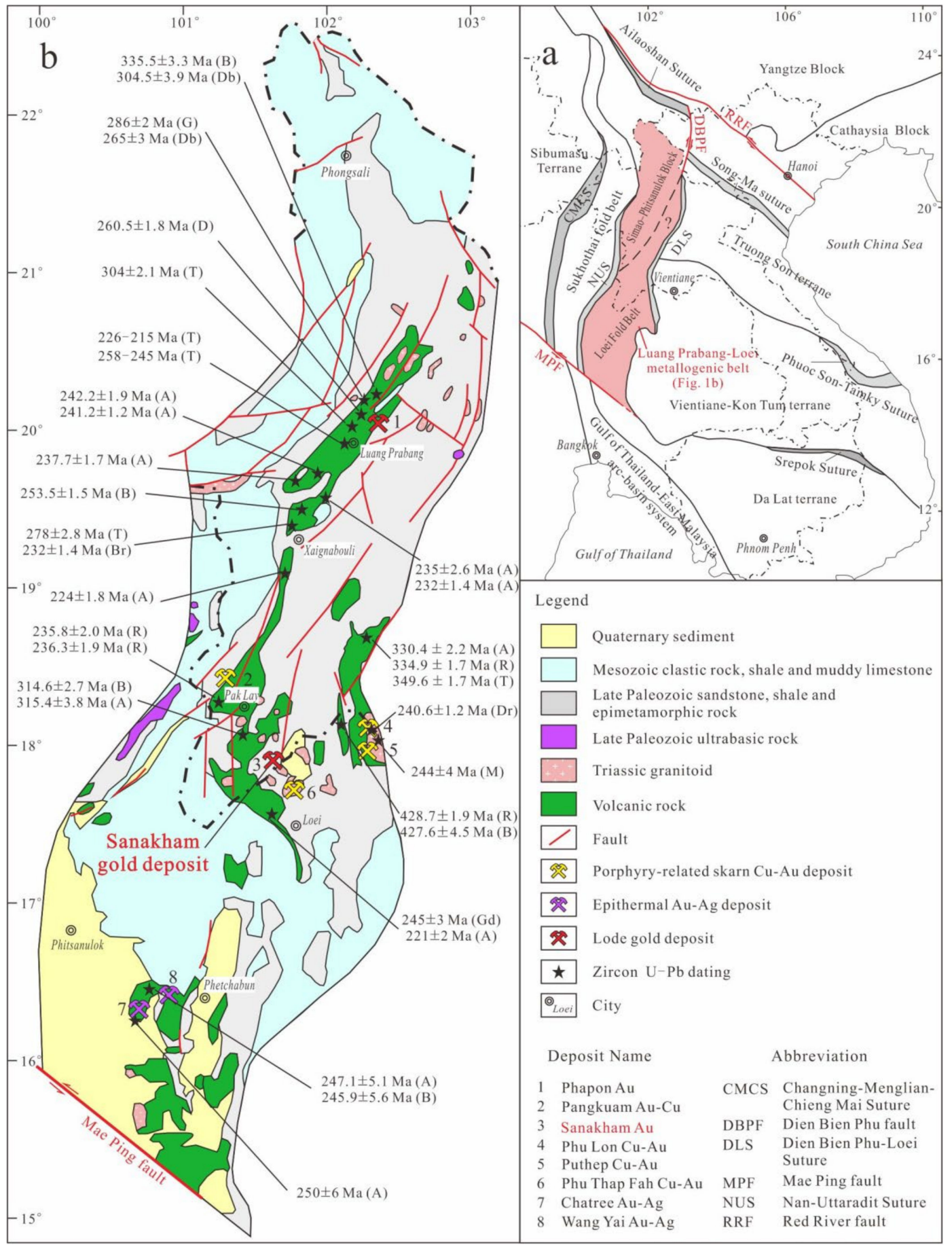

Figure 1. Regional geological map. (a) Simplified tectonic map showing structural units of Laos andadjacent regions; (b) simplified geological map of the Luang Prabang-Loei metallogenic belt (geochronological data from [4-16], modified from [5,10]). A = andesite; $\mathrm{B}=$ basalt; $\mathrm{Br}=\mathrm{breccia}$; $\mathrm{D}=$ dacite; $\mathrm{Db}=$ diabase; $\mathrm{Dr}=$ diorite; $\mathrm{G}=$ gabbro; $\mathrm{Gd}=$ Granodiorite; $\mathrm{M}=$ monzonite; $\mathrm{R}=$ rhyolite; $\mathrm{T}=$ tuff.

The Sanakham gold deposit, a newly discovered gold deposit in this belt with a gold resource of $10.6 \mathrm{t} @ 3.05 \mathrm{~g} / \mathrm{t} \mathrm{Au}$, is located about $3 \mathrm{~km}$ north to the Muang Sanakham County, southwest Laos (Figure 1b). The gold orebodies consist of a series of quartz-sulfide veins that are controlled by secondary structures of the regional NNE-trending brittle-ductile shear zone, which is different from the regional porphyry-related skarn and epithermal 
gold deposits. Given it is such a particular lode gold deposit in the Luang Prabang-Loei belt, studying it should be meaningful in both prospecting and theory. Nevertheless, there are no reports of studies on the Sanakham gold deposit up to now. We therefore carried out detailed petrography, microthermometry, and Laser Raman spectroscopy on fluid inclusions in gold-related quartz from different mineralization stages, identified by field and microscopic observation. This study aims to discuss the evolution of ore-forming fluids and gold deposition mechanisms in Sanakham, and to provide basic data for further study on regional gold metallogenic regularity.

\section{Geology and Mineralization}

\subsection{Regional Geological Setting}

The Luang Prabang-Loei metallogenic belt is NNE-NE trending, bounded by the Dien Bien Phu-Loei Suture (DLS) to the east, the Nan-Uttaradit Suture (NUS) to the west, and the Meiping Fault (MPF) to the south, and is adjacent to the Simao Block in the Sanjiang Region to the north [1]. The NE-trending Luang Prabang tectonic belt develops in the centralnorthern part of the metallogenic belt (Figure 1a); it is characterized by a large number of Late Paleozoic-Mesozoic intermediate-basic magmatic rocks, including pillow-shaped basalts, andesites, gabbro, diabase, diorite, and volcanic clastic rocks (Figure 1b). The Carboniferous magmatic rocks, including basalt, andesite, and diabase, mainly occurred around Luang Prabang and Pak Lay [5-7]. The Permian to Early Triassic igneous rocks are normally gabbro, diabase, tuff, and diorite, and are confined around Luang Prabang and Xaignabouli [4,8-10]. The Middle-Late Triassic exposed intermediate-acid igneous rocks are widespread in the belt $[5,9,11,12]$. Some important gold deposits occurred in the Luang Prabang tectonic belt, including orogenic Au (Phapon [17,18]), skarn gold-copper (Pangkuam [19]), and the Sanakham lode gold deposit.

The northwest side of the Luang Prabang tectonic belt belongs to the Simao-Phitsanulok Block (Figure 1a), which is regarded as a back-arc foreland basin [1]. It mainly consists of Late Paleozoic sandstone, shale, and epimetamorphic rocks, Triassic clastic rocks and carbonate rocks, and Middle Jurassic red clastic rocks [10]. Only a few copper occurrences are found in the basin.

The southeast side of the Luang Prabang tectonic belt is the Loei Fold Belt (Figure 1a), with Late Paleozoic and Mesozoic sediments and volcanic rocks [6,13], as well as EarlyMiddle Triassic magmatic rocks exposed (Figure 1b). The representative porphyry-skarn copper-gold deposits (Phu Lon, Puthep, and Phu Thap Fah) develop to the north and northeast of Loei in Thailand and are genetically related with the felsic-intermediate intrusive rocks $[14,15]$. A set of Late Permian to Early Triassic andesitic-rhyolitic volcanic and pyroclastic rocks develops in the south of the metallogenic belt, associated with several epithermal $\mathrm{Au}-\mathrm{Ag}$ deposits [16].

\subsection{Local Geological Setting}

The main stratum in the mining area is the Upper Carboniferous Nanpo Formation $\left(\mathrm{C}_{2} \mathrm{n}\right)$, which consist of purple-red thick-layered metamorphic siltstone, silty slate, slate, and brown thin-layered feldspar-debris sandstone (Figure 2). It is N to NNE trending, generally dipped to the west with a dip angle of $60-85^{\circ}$, and is more than $600 \mathrm{~m}$ in thickness. The Quaternary sediments $(Q)$, which mainly consists of fragments that came from slate, carbonaceous slate, and metamorphic siltstone, are widespread on gentle slopes and platforms in various areas of the mining area.

The structures in the mine are mainly brittle-ductile shear zone, fault, and fracture (Figure 2). The brittle-ductile shear zone trends northeast, consistent with the regional Luang Prabang structural belt, and generally controls the overall output of the orebodies. The faults are secondary structures of the regional brittle-ductile shear zone and trend NNE or nearly S-N. They control the main intrusions and geological boundaries in the mining area. Gold orebodies normally occur within the faults and their secondary fractures. 

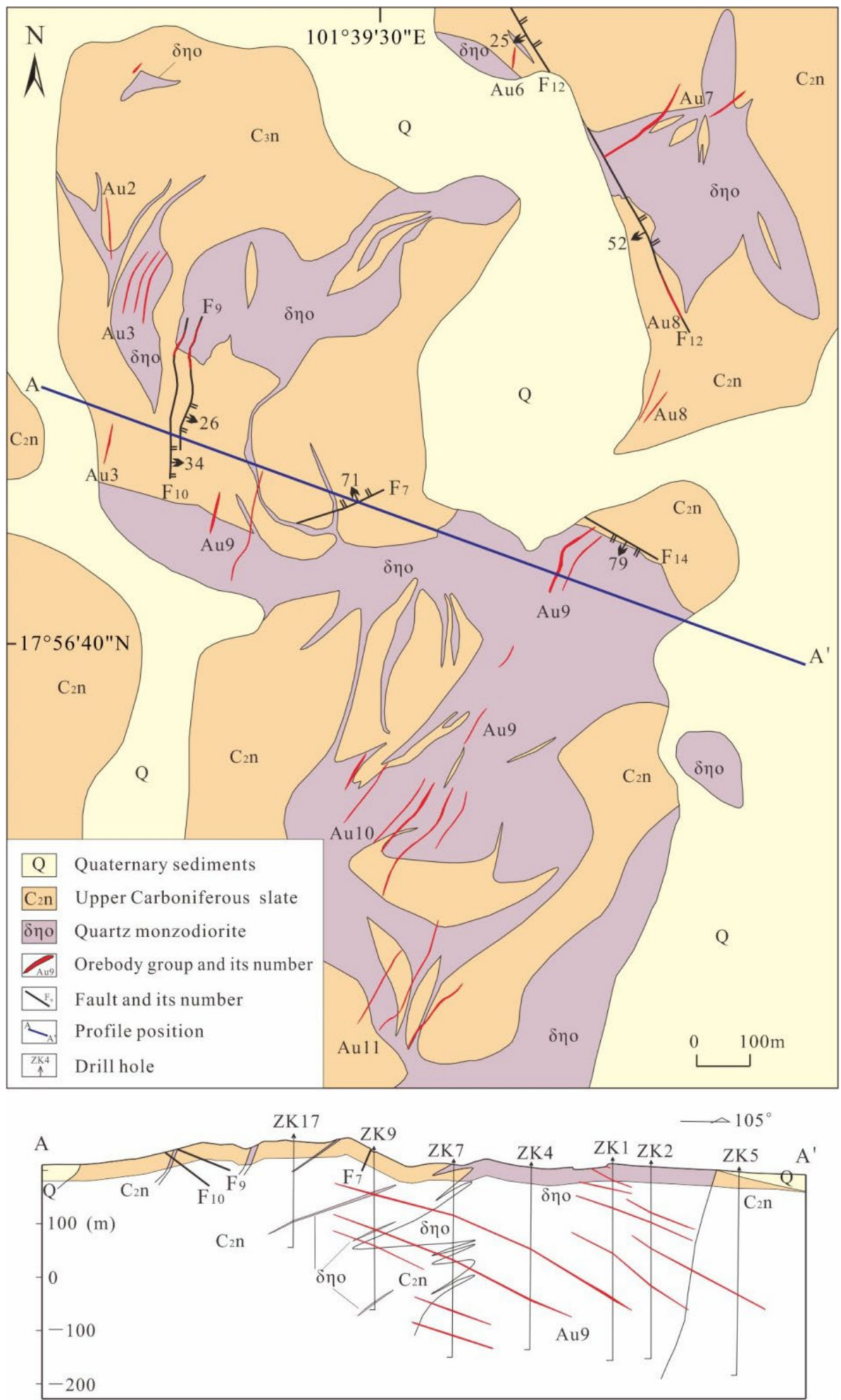

Figure 2. Simplified geological map of the Sanakham gold deposit and geological cross-sections along line $\mathrm{AA}^{\prime}$.

The Middle Triassic intermediate-acid magmatic rocks are well developed and intruded into the Upper Carboniferous low-grade metamorphic rocks as an NNE-trending intrusive stock (Figure 2). The intrusions mainly consist of quartz monzodiorite with a hypidiomorphic granular texture and massive structure. It is composed of plagioclase, 
amphibole, alkaline feldspar, a small amount of quartz, and trace amounts of pyrite in size of 0.1-4 mm, and is gray-white in color because of weathering.

Ninety-one gold orebodies have been identified in the Sanakham deposit, and they can be divided into more than ten orebody groups (Figure 2). Most of the orebodies, vein or veinlet in shape, are included in the Au9 orebody group and account for 3/4 of the total gold resources. The several main orebodies in the Au9 orebody group are about $80-400 \mathrm{~m}$ in length, strike towards the NE, and dip $10^{\circ}-40^{\circ} \mathrm{SE}$ with a depth of 300-600 m. They range in thickness from 0.8 to $4 \mathrm{~m}$, averaging about $1.2-1.5 \mathrm{~m}$. The gold grade ranges from 1.0 to $12.3 \mathrm{~g} / \mathrm{t}$, with an average gold grade of $3.05 \mathrm{~g} / \mathrm{t}$. The wallrocks are generally quartz monzonite, slate, and, locally hornfel.

\subsection{Wall-Rock Alterations and Ore Mineralization}

The wall-rock alteration at Sanakham mainly developed in the quartz monzodiorite and is controlled by the NE-NNE trending faults. The hydrothermal alterations are primarily silicification, sulfidation, sericitization, and carbonation, among which silicification and sulfidation have the closest relationship with gold mineralization. Silicification is the most widely distributed alteration, normally occurred as veins and networks, with a small amount disseminated in the intrusions. Sulfidation is dominated by pyrite, and lesser pyrrhotite, chalcopyrite, arsenopyrite, galena, and sphalerite. They co-exist with quartz to form quartz-sulfide veins (Figure 3a-d), generally as banded sulfide assemblages or massive aggregates (Figure $3 \mathrm{e}-\mathrm{f}$ ). The plagioclase, biotite, and potassium feldspar are locally subjected to sericitization around the orebodies, showing a coexistence relationship with disseminated silicification. Carbonation is normally in the form of calcite veinlets, 0.1 to $1 \mathrm{~cm}$ in width, interspersed in the wall rock. K-feldspar and chlorite are widely distributed in the intrusions and formed earlier than gold-related mineralization. Hydrothermal metasomatic alteration develops along the contact zones between quartz monzonite and slate, with a width of less than $20 \mathrm{~m}$. It is characterized by skarnization, marbleization and hornfel alteration, but has little spatial relation with gold mineralization.

The lode gold orebodies primarily occur in the fault zones and fractures in the quartz monzodiorite and locally extend into Upper Carboniferous strata along with the structures. Primary sulfide ores mainly present vein stockwork and massive structures followed by disseminated structures. The ore minerals are primarily pyrite ( 10 vol\%), with lesser chalcopyrite and pyrrhotite (each $2-3 \mathrm{vol} \%$ ), and a small amount of arsenopyrite, galena, and sphalerite (each $\sim 1 \mathrm{vol} \%$ ); the gangue minerals mainly consist of quartz (60-70 vol\%) with minor calcite (5-10 vol\%) and lesser sericite (1-3 vol\%). Based on cross-cutting relationships and mineral assemblage characteristics (Figure 3), four mineralization stages have been identified in Sanakham (Figure 4): quartz-pyrite-arsenopyrite (stage I), quartzpyrite-pyrrhotite-chalcopyrite (stage II), quartz-pyrite-base-metal sulfide (stage III), and quartz-carbonate (stage IV). Native gold occurs mainly in the main ore stages, i.e., stages II and III.

Stage I is normally quartz veins that comprise milky white quartz (Figure 3a), minor sericite, and euhedral to subhedral coarse-grained disseminated pyrite (Figure 3g) and arsenopyrite (Figure 3i). Stage II is characterized by quartz-sulfide veins and veinlets in grey color. The minerals are primarily subhedral to anhedral fine-grained pyrite, with minor pyrrhotite and chalcopyrite, which normally occurs around the boundary of stage I pyrite and arsenopyrite (Figure 3h,i). Native gold appears generally as irregular inclusions in pyrrhotite or chalcopyrite that fill in fractures of pyrite (Figure 3j,k). Similarly, stage III is characterized by quartz-sulfide veins and sulfide massive aggregations that consist of quartz, pyrite, pyrrhotite, chalcopyrite, and galena and sphalerite in particular (Figure 31). They normally crosscut or overprint the stage II veins. Stage IV is characterized by quartzcalcite veinlets that crosscut the quartz-sulfide veins (Figure 3d). 

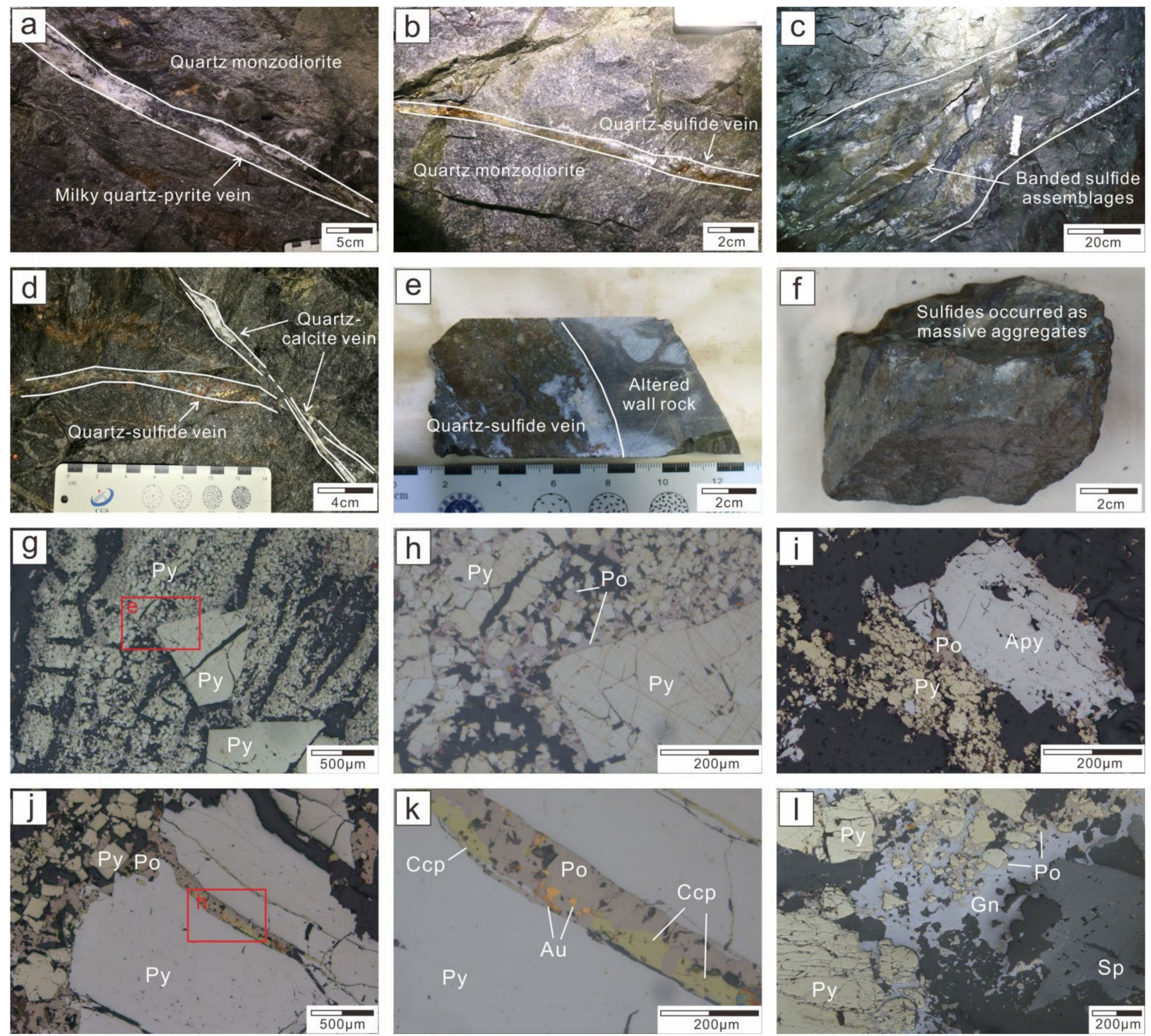

Figure 3. Typical alteration and mineralization in the Sanakham gold deposit (d-i are reflected light images). (a), Milky quartz-pyrite vein in quartz monzodiorite; (b), quartz-sulfide vein in quartz monzodiorite; (c), banded sulfide assemblages; (d), quartz-calcite vein crosscut quartz-sulfide vein; (e), coexistence of sulfides and quartz in hand sample; (f), sulfides occurred as massive aggregates; $(\mathbf{g}, \mathbf{h})$, stage I euhedral to subhedral coarse-grained pyrite and stage II subhedral to anhedral finegrained pyrite and pyrrhotite; (i), stage II pyrite and pyrrhotite occurred around stage I arsenopyrite; $(\mathbf{j}, \mathbf{k})$, native gold coexisting with pyrrhotite or chalcopyrite that fills in fractures of pyrite; (1), sulfide aggregations in stage III. Apy, arsenopyrite; Au, native gold; Ccp, chalcopyrite; Gn, galena; Po, pyrrhotite; Py, pyrite. 


\begin{tabular}{|c|c|c|c|c|}
\hline Mineral & Stage I & Stage II & Stage III & Stage IV \\
\hline Quartz & & & & \\
\hline Sericite & & & & \\
\hline & & & & \\
\hline Pyrite & & & & \\
\hline Arsenopyrite & & & & \\
\hline Pyrrhotite & & & & \\
\hline Chalcopyrite & & & & \\
\hline Native gold & & & & \\
\hline Colomo & & & & \\
\hline Galena & & & & \\
\hline Sphalerite & & & & \\
\hline Calcite & & & & \\
\hline
\end{tabular}

Figure 4. Paragenetic sequence of hydrothermal minerals in the Sanakham gold deposit, with line thickness indicating the relative abundance of minerals.

\section{Sampling and Analytical Methods}

A total of nine samples of gold-bearing ore were selected for fluid-inclusion analyses. Twenty doubly polished sections (about $0.1 \mathrm{~mm}$ thick) were chosen for petrographical study; of these, twelve sections were selected for microthermometry and Laser Raman study on hydrothermal quartz grains at the Fluid Inclusion Laboratories, Chengdu Center of China Geological Survey.

Fluid inclusion microthermometry was made with a Linkam THMSG 600 heatingcooling stage $\left(-198\right.$ to $\left.600^{\circ} \mathrm{C}\right)$. The reproducibility of measurements was $\pm 1{ }^{\circ} \mathrm{C}$ at temperatures $>30{ }^{\circ} \mathrm{C}$ and $\pm 0.1{ }^{\circ} \mathrm{C}$ at temperatures $<30{ }^{\circ} \mathrm{C}$. The measurements of melting temperatures of ice ( $T_{\mathrm{m}}$ ice), melting temperatures of the carbonic phase (mainly consist of $\mathrm{CO}_{2}$ and $\mathrm{CH}_{4}, T_{\mathrm{m}}$ carbon $)$, clathrate-melting temperatures ( $\left.T_{\mathrm{m} \text { clath }}\right)$, and partial homogenization of carbonic phase $\left(T_{\mathrm{h} \text { carbon }}\right)$ were made at the heating rate of $0.2^{\circ} \mathrm{C} / \mathrm{min}$, and for final homogenization temperature $\left(T_{\mathrm{h} \text { тот }}\right)$, the heating rate was $1.0^{\circ} \mathrm{C} / \mathrm{min}$.

Laser Raman spectroscopy of individual inclusions was performed using a Renishaw Raman spectrometer equipped with a $514 \mathrm{~nm}$ Ar ion laser as the source of excitation. The instrument records peaks in the range of 1200 to $3800 \mathrm{~cm}^{-1}$ with a resolution of $\pm 1 \mathrm{~cm}^{-1}$ and a spectral repeatability of less than $0.1 \mathrm{~cm}^{-1}$.

\section{Results}

\subsection{Fluid-Inclusion Petrography}

Based on micro-observation, microthermometry and Laser Raman analyses, the fluid inclusions were classified and grouped according to textural criteria using the FIA (fluid inclusion assemblage) method [20,21]. Three gold-related primary fluid inclusion types were observed in quartz: type $\mathrm{M}, \mathrm{CH}_{4}$-rich fluid inclusion; type $\mathrm{C}, \mathrm{CO}_{2}$-rich fluid inclusion; and type $W$, aqueous inclusions. Type $M$ inclusions normally comprise a carbonic vapor phase and an aqueous phase at room temperature (Figure 5a). The carbonic phase consists primarily of $\mathrm{CH}_{4}$, less of $\mathrm{CO}_{2}$, and occasionally of $\mathrm{C}_{2} \mathrm{H}_{6}$ and $\mathrm{H}_{2} \mathrm{~S}$, and separates into vapor and liquid carbonic phases through cooling (Figure $5 b$ ). These inclusions have a continuum $\mathrm{V} /(\mathrm{L}+\mathrm{V})$ ratios range from 0.3 to 0.8 and homogenize to either liquid or vapor. Daughter minerals can be occasionally found in individual type $M$ inclusions (Figure 5c). Type $C$ inclusions contain two (aqueous + carbonic) or three (aqueous + liquid carbonic + vapor carbonic) phases at room temperature, and can be further divided into two subtypes based on their $\mathrm{V} /(\mathrm{L}+\mathrm{V})$ ratios: type $\mathrm{C} 1$ has $\mathrm{V} /(\mathrm{L}+\mathrm{V})$ ratios mostly between 0.1 and 0.3 and homogenizes into liquid (the aqueous phase, Figure $5 \mathrm{~d}$ ), whereas type $C 2$ has $\mathrm{V} /(\mathrm{L}+\mathrm{V})$ ratios of 0.6 and 0.9 and normally homogenizes into vapor (the carbonic phase, Figure 5e). 
The carbonic phase of type $C$ inclusions consists of major $\mathrm{CO}_{2}$ and less $\mathrm{CH}_{4}$, which is different from type $M$ inclusions. Type $W$ aqueous inclusions comprise an aqueous phase and a vapor phase with $\mathrm{V} /(\mathrm{L}+\mathrm{V})$ ratios of 0.05 to 0.25 , and homogenize to liquid (Figure $5 \mathrm{f}$ ). The type $M$ and $C$ inclusions are normally 5-15 $\mu \mathrm{m}$ in diameter, have predominately regular to negative crystal shape or partly irregular shape. The type $W$ inclusions are relatively smaller $(2-10 \mu \mathrm{m})$ and have regular to irregular shape.

Six groups of FIA occur in hydrothermal quartz grains and are summarized in Table 1. Group 1 FIA consists of type $M$ inclusions that show nearly constant $V /(L+V)$ ratios, and widely distributed as clusters in stage I quartz (Figure 5g). Group 2 FIA, composed of C1 inclusions sharing the same composition, locally occurs as clusters in stage II quartz (Figure 5h). Group 3 FIA consists of $M$ and $C 1$ inclusions that widely occur as clusters in stage II quartz and show various volumes of the carbonic phases (Figure 5i). Group 4 FIA, also composed of $C 1$ inclusions sharing the same composition, exists in stage III quartz, either as clusters, or along pseudo-secondary trails, or as isolated inclusions (Figure 5j). Group 5 FIA is distinctive and widespread in stage III quartz and consists of type C1 and $\mathrm{C} 2$ inclusions. The coexisting $\mathrm{C} 1$ and $\mathrm{C} 2$ inclusions have different $\mathrm{V} /(\mathrm{L}+\mathrm{V})$ ratios and homogenize to liquid and vapor, respectively (Figure 5k,l). Group 6 FIA generally occurred in stage IV quartz and was comprised of $W$ inclusions with identical $V /(L+V)$ ratios (Figure 5m).

Table 1. Summary of the fluid inclusion and FIA groups in hydrothermal quartz from four mineralization stages.

\begin{tabular}{ccccc}
\hline Ore Stage & FIA Group & Fluid Inclusion Type & $\begin{array}{c}\text { Frequency of } \\
\text { Occurrences }\end{array}$ & $\begin{array}{c}\text { Implication For Ore } \\
\text { Fluids Processes }\end{array}$ \\
\hline Stage I & Group 1 & $M$ & Abundant & Homogeneous fluid \\
\hline \multirow{2}{*}{ Stage II } & Group 2 & $C 1$ & Local & Homogeneous fluid \\
\cline { 2 - 5 } & Group 3 & $M+C 1$ & Abundant & Fluid immiscibility \\
\cline { 2 - 5 } Stage III & Group 4 & $C 1$ & Local & Homogeneous fluid \\
\hline Stage IV & Group 5 & $C 1+C 2$ & Abundant & Fluid immiscibility \\
\hline & Group 6 & $W$ & Abundant & Homogeneous fluid \\
\hline
\end{tabular}

\subsection{Results of Microthermometry}

A total of 23 FIAs selected from hydrothermal quartz from all four stages were analyzed. The microthermometric data and calculated parameters (min, max, mean and number) for every FIA are listed in Tables 2-5. Of which, mean values of each type of fluid inclusions in every FIA are used for assessment and math statistics.

\subsubsection{FIA in Stage I}

Four Group 1 FIAs, each comprising 3-5 inclusions, were measured to gain exact microthermometry data (Table 2 and Figure 6 ). The $T_{\mathrm{m} \text { carbon }}$ of type $M$ inclusions occurs between -74.2 and $-69.5^{\circ} \mathrm{C}$, with a mean value of $-72.2^{\circ} \mathrm{C}$. The $T_{\mathrm{m} \text { clath }}$ and $T_{\mathrm{h} \text { carbon }}$ of type $M$ inclusions range from -5.7 to $-2.9^{\circ} \mathrm{C}$ (mean $-4.2^{\circ} \mathrm{C}$ ), and 4.9 to $9.5^{\circ} \mathrm{C}$ (mean $6.8^{\circ} \mathrm{C}$ ), relatively. These inclusions generally homogenize into liquid phase finally, with $\mathrm{T}_{\mathrm{h} \text { TOT }}$ between $326^{\circ}$ and $345^{\circ} \mathrm{C}$ (mean $337^{\circ} \mathrm{C}$ ). 

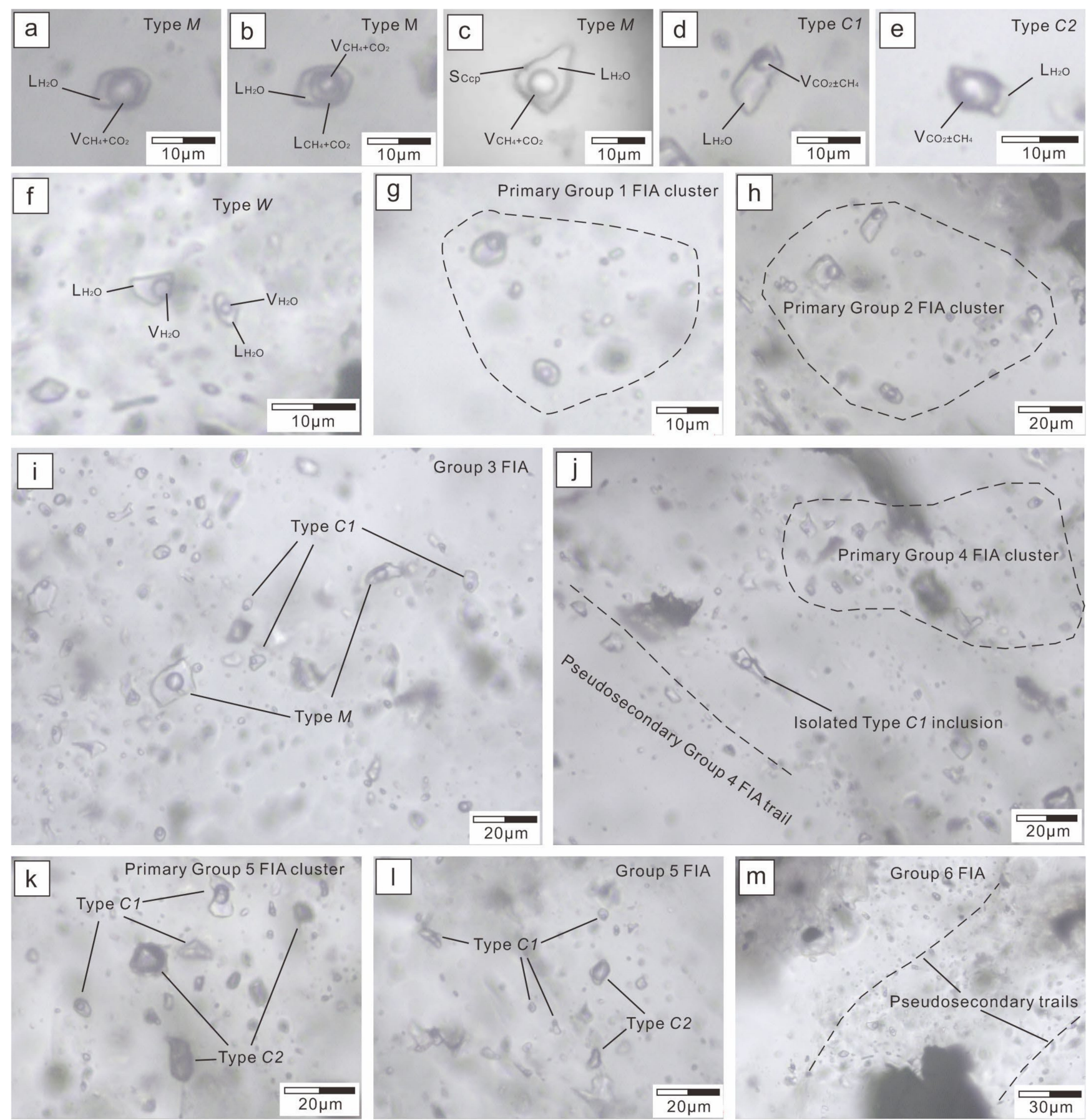

Figure 5. Photomicrographs of typical fluid inclusions and FIA groups in the Sanakham gold deposit. (a) Typical type $\mathrm{MCH}_{4}$-rich fluid inclusion consisting of $\mathrm{H}_{2} \mathrm{O}$ liquid and carbonic vapor $\left(\mathrm{CH}_{4}+\mathrm{CO}_{2}\right.$ $\left.\pm \mathrm{C}_{2} \mathrm{H}_{6} \pm \mathrm{H}_{2} \mathrm{~S}\right)$ phases at room temperature; (b) type $M$ FI consisting of three $\left(\mathrm{H}_{2} \mathrm{O}\right.$ liquid + carbonic liquid + carbonic vapor) phases at about $-20^{\circ} \mathrm{C}$; (c) type $\mathrm{M} \mathrm{CH}_{4}$-rich fluid inclusion with daughter mineral (chalcopyrite); (d) type $\mathrm{C} 1$ liquid-rich $\mathrm{CO}_{2}$ inclusion; (e) type $\mathrm{C} 2$ vapor-rich $\mathrm{CO}_{2}$ inclusion; (f) type $\mathrm{W}$ two-phase $\mathrm{H}_{2} \mathrm{O}-\mathrm{NaCl}$ inclusion; (g) primary cluster of Group 1 FIA in stage I quartz; (h) primary cluster of Group 2 FIA in stage II quartz; (i) group 3 FIA in stage II quartz consisting of type $M$ and $C 1$ inclusions with various volumes of the carbonic phases; (j) Group 4 FIA occurred as cluster, pseudo-secondary trail, and isolated type C1 inclusions in stage III quartz; (k) primary cluster of Group 5 FIA consisting of type C1 and C2 inclusions showing opposite modes of homogenization at approximately the same temperature; (1) pseudo-secondary Group 5 FIA trail in stage III quartz; (m) pPseudo-secondary Group 6 FIA trails containing type $W$ fluid inclusions in stage IV quartz. 

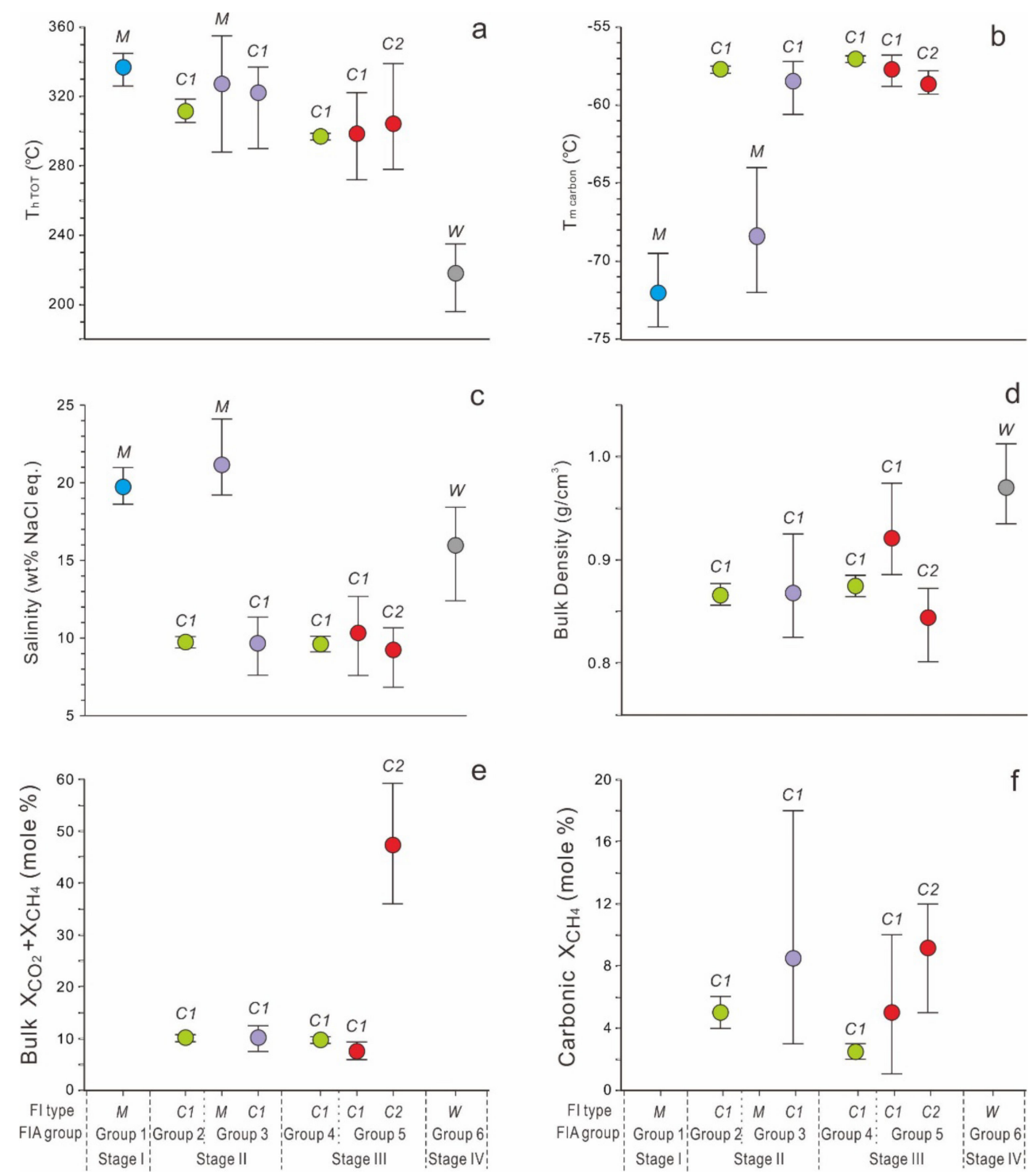

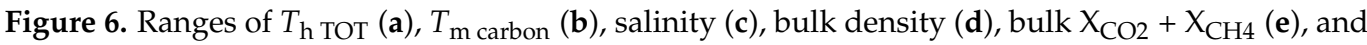
carbonic $\mathrm{X}_{\mathrm{CH} 4}$ (f) versus Groups 1-6 FIA in the four stages, respectively. The points in the middle of the bars are the mean value.

\subsubsection{FIA in Stage II}

Two Group 2 FIAs, which are comprised of four type $C 1$ inclusions each, were measured successfully (Table 3 and Figure 6$)$. The $T_{\mathrm{m} \text { carbon, }} T_{\mathrm{m} \text { clath }}, T_{\mathrm{h} \text { carbon, }}$ and $T_{\mathrm{h} \text { TOT }}$ of $\mathrm{C} 1$ inclusions in Group 2 FIA are -57.9 to $-57.5^{\circ} \mathrm{C}$ (mean $-57.7^{\circ} \mathrm{C}$ ), 4.3 to $4.8^{\circ} \mathrm{C}$ (mean $4.6^{\circ} \mathrm{C}$ ), 18.2 to $20.3^{\circ} \mathrm{C}$ (mean $19.3^{\circ} \mathrm{C}$ ), and 305 to $318^{\circ} \mathrm{C}$ (mean $312^{\circ} \mathrm{C}$ ), respectively. The microthermometric data are similar to those in Group 1 FIA in stage I quartz.

Six Group 3 FIAs, which are widespread in stage II quartz and consist of several coexisting type $M$ and $C 1$ inclusions, were chosen for microthermometry (Table 3 and Figure 6). The $T_{\mathrm{m} \text { carbon }}$ of type $M$ inclusions occurs between -72.0 and $-64.0{ }^{\circ} \mathrm{C}$ (mean $-68.4{ }^{\circ} \mathrm{C}$ ), while the type $C 1$ inclusions have an obviously higher $T_{\mathrm{m}}$ carbon range from -60.6 and $-57.2{ }^{\circ} \mathrm{C}$ (mean $-58.5^{\circ} \mathrm{C}$ ). The $T_{\mathrm{m}}$ clath and $T_{\mathrm{h} \text { carbon }}$ of type $M$ inclusions range from -9.8 to $-3.7^{\circ} \mathrm{C}$ (mean $-6.1^{\circ} \mathrm{C}$ ) and 4.3 to $16.2^{\circ} \mathrm{C}$ (mean $9.7^{\circ} \mathrm{C}$ ), respectively. Similarly, the type $\mathrm{C} 1$ inclusions have a higher $T_{\mathrm{m}}$ clath and $T_{\mathrm{h} \text { carbon }}$ range from 3.5 to $5.9^{\circ} \mathrm{C}$ (mean $4.6^{\circ} \mathrm{C}$ ) and 16.4 to $23.3^{\circ} \mathrm{C}$ (mean $19.5^{\circ} \mathrm{C}$ ), respectively. The $M$ inclusions generally homogenize finally into the liquid phase with $T_{\mathrm{h}}$ тот between $288^{\circ}$ and $355^{\circ} \mathrm{C}$ (mean 
$327^{\circ} \mathrm{C}$ ). All of the type $\mathrm{C} 1$ inclusions finally homogenize into the liquid phase and occur generally between $290^{\circ}$ and $337^{\circ} \mathrm{C}$, with a mean value of $322^{\circ} \mathrm{C}$.

Table 2. Summary of the microthermometric data and calculated parameters for Group 1 FIAs from stage I quartz.

\begin{tabular}{|c|c|c|c|c|c|c|c|c|}
\hline FIA Group & FIA No. & FI Type & Range & $\mathrm{T}_{\mathrm{m} \text { carbon }}\left({ }^{\circ} \mathrm{C}\right)$ & $\mathrm{T}_{\mathrm{m} \text { clath }}\left({ }^{\circ} \mathrm{C}\right)$ & $\mathrm{T}_{\mathrm{h} \text { carbon }}\left({ }^{\circ} \mathrm{C}\right)$ & $\begin{array}{c}\mathrm{T}_{\mathrm{h} \text { TOT }} \\
\left({ }^{\circ} \mathrm{C}\right)\end{array}$ & $\begin{array}{c}\text { Salinity } \\
\text { (wt. \% NaCl) }\end{array}$ \\
\hline \multirow[t]{12}{*}{ Group 1} & \multirow[t]{3}{*}{ Group 1-1 } & \multirow{3}{*}{$\begin{array}{c}M \\
(\mathrm{~N}=5)\end{array}$} & Min & -76.1 & -3.5 & 7.8 & 328 & 17.9 \\
\hline & & & Max & -70.3 & -2.2 & 11.1 & 352 & 19.1 \\
\hline & & & Mean & -74.2 & -2.9 & 9.5 & 340 & 18.6 \\
\hline & \multirow[t]{3}{*}{ Group 1-2 } & \multirow{3}{*}{$\begin{array}{c}M \\
(\mathrm{~N}=4)\end{array}$} & Min & -74.4 & -4.7 & 3.1 & 336 & 18.8 \\
\hline & & & Max & -71.1 & -3.1 & 6.7 & 352 & 20.2 \\
\hline & & & Mean & -72.8 & -3.9 & 4.8 & 345 & 19.5 \\
\hline & \multirow[t]{3}{*}{ Group 1-3 } & \multirow{3}{*}{$\begin{array}{c}M \\
(\mathrm{~N}=4)\end{array}$} & Min & -73.5 & -5.5 & 4.9 & 329 & 19.4 \\
\hline & & & Max & -70.1 & -3.8 & 8.2 & 346 & 20.9 \\
\hline & & & Mean & -71.6 & -4.6 & 6.6 & 337 & 20.1 \\
\hline & \multirow[t]{3}{*}{ Group 1-4 } & \multirow{3}{*}{$\begin{array}{c}M \\
(\mathrm{~N}=3)\end{array}$} & Min & -70.5 & -7.4 & 5.2 & 317 & 19.8 \\
\hline & & & Max & -68.7 & -4.2 & 7.0 & 341 & 22.4 \\
\hline & & & Mean & -69.5 & -5.7 & 6.0 & 326 & 21.0 \\
\hline
\end{tabular}

\subsubsection{FIA in Stage III}

For the local existed Group 4 FIAs (Table 4 and Figure 6 ), the $T_{\text {m carbon, }} T_{\text {m clath }}$ $T_{\mathrm{h} \text { carbon, }}$ and $T_{\mathrm{h} \text { TOT }}$ of type $\mathrm{C} 1$ inclusions are, respectively, -57.2 to $-57.0^{\circ} \mathrm{C}$ (mean $-57.1^{\circ} \mathrm{C}$ ), 4.3 to $5.0^{\circ} \mathrm{C}$ (mean $4.7^{\circ} \mathrm{C}$ ), 22.0 to $23.3^{\circ} \mathrm{C}\left(\right.$ mean $22.7^{\circ} \mathrm{C}$ ), and 296 to $298{ }^{\circ} \mathrm{C}$ (mean $297^{\circ} \mathrm{C}$ ), which are generally similar to the Group 2 FIAs in stage II quartz.

The coexisting type $C 1$ and $C 2$ inclusions in the six measured Group 5 FIAs have the similar microthermometric data (Table 4 and Figure 6 ). The $T_{\mathrm{m}}$ carbon of type $C 1$ inclusions occur between -58.8 and $-56.8^{\circ} \mathrm{C}$, with a mean value of $-57.7^{\circ} \mathrm{C}$. The type $\mathrm{C} 2$ inclusions have slightly lower $T_{\mathrm{m}}$ carbon range from -59.3 and $-57.8^{\circ} \mathrm{C}$ (mean $-58.7^{\circ} \mathrm{C}$ ). The $T_{\mathrm{m}}$ clath and $T_{\mathrm{h} \text { carbon }}$ of type $\mathrm{C} 1$ inclusions range relatively from 2.5 to $5.9^{\circ} \mathrm{C}$, and 16.9 to $24.0^{\circ} \mathrm{C}$. While, the type $C 2$ inclusions have slightly higher $T_{\mathrm{m}}$ clath and $T_{\mathrm{h}}$ carbon relatively from 4.9 to $6.4^{\circ} \mathrm{C}$, and 18.3 to $25.4^{\circ} \mathrm{C}$. The $\mathrm{C} 1$ and $\mathrm{C} 2$ inclusions finally homogenize into liquid and vapor phase, with $T_{\mathrm{h} \text { TOT }}$ of $272^{\circ}$ to $322^{\circ} \mathrm{C}$ (mean $299^{\circ} \mathrm{C}$ ) and $278^{\circ}$ to $339{ }^{\circ} \mathrm{C}$ (mean $\left.304^{\circ} \mathrm{C}\right)$, respectively. Some coexisting $\mathrm{C} 1$ and $\mathrm{C} 2$ inclusions have their $\mathrm{V} /(\mathrm{L}+\mathrm{V})$ ratios change during heating, but cracked almost simultaneously before final homogenization.

\subsubsection{FIA in Stage IV}

Three Group 6 FIAs which comprise 4-5 type $W$ inclusions in each were selected for microthermometry (Table 5 and Figure 6). The type $W$ inclusions have melting temperatures of ice $\left(T_{\text {m ice }}\right)$ range from -14.5 to $-8.6^{\circ} \mathrm{C}$ (mean $\left.-11.3^{\circ} \mathrm{C}\right)$, and total homogenization into liquid occurs between 196 and $235^{\circ} \mathrm{C}$ (mean $\left.218^{\circ} \mathrm{C}\right)$.

\subsection{Results of Laser Raman Spectroscopy}

Laser Raman spectroscopy indicates that both type $M$ and type $C$ fluid inclusions have carbonic component-dominate vapor phase (Figure 7). The gas phases of these inclusions consist of $\mathrm{CH}_{4}+\mathrm{CO}_{2} \pm \mathrm{C}_{2} \mathrm{H}_{6} \pm \mathrm{H}_{2} \mathrm{~S}$, with no detectable $\mathrm{N}_{2}$. The type $C$ inclusions normally have high $\mathrm{CO}_{2}$ spectroscopic peaks (Figure 7a), while most spectroscopic analyses show high $\mathrm{CH}_{4}$ peaks in type $M$ inclusions (Figure $7 \mathrm{~b}-\mathrm{d}$ ). Type $M$ inclusions contain about 70-85 mole \% $\mathrm{CH}_{4}$ in carbonic phase, much higher than that of $\mathrm{C} 1$ inclusions $\left(\mathrm{CH}_{4}\right.$ contents normally lower than $20 \%$ ). The occasional daughter minerals in type $M$ inclusions are normally chalcopyrite (Figure 7d) and calcite. 
Table 3. Summary of the microthermometric data and calculated parameters for Groups 2 and 3 FIAs from stage II quartz.

\begin{tabular}{|c|c|c|c|c|c|c|c|c|c|c|c|c|c|c|}
\hline FIA Group & FIA No. & FI Type & Range & $\mathrm{T}_{\mathrm{m} \text { carbon }}\left({ }^{\circ} \mathrm{C}\right)$ & $\mathrm{T}_{\mathrm{m} \text { clath }}\left({ }^{\circ} \mathrm{C}\right)$ & $\mathrm{T}_{\mathrm{h} \text { carbon }}\left({ }^{\circ} \mathrm{C}\right)$ & $\mathrm{T}_{\mathrm{h} \text { тот }}\left({ }^{\circ} \mathrm{C}\right)$ & $\begin{array}{c}\text { Salinity } \\
\text { (wt.\% NaCl) }\end{array}$ & $\begin{array}{l}\text { Bulk Density } \\
\left(\mathrm{g} / \mathrm{cm}^{3}\right)\end{array}$ & $\mathrm{XH}_{2} \mathrm{O}$ & $\mathrm{XNaCl}$ & $\underset{\mathrm{XCO}_{4}}{\mathrm{XCO}_{4}}$ & $\mathrm{XCO}_{2}$ & $\mathrm{XCH}_{4}$ \\
\hline \multirow[t]{5}{*}{ Group 2} & Group 2-1 & $C 1$ & Min & -58.6 & 3.9 & 16.5 & 295 & 9.4 & 0.782 & 0.825 & 0.026 & 0.051 & 0.046 & 0.005 \\
\hline & - & $(\mathrm{N}=4)$ & $\operatorname{Max}$ & -57.2 & 4.8 & 20.6 & 314 & 10.7 & 0.983 & 0.915 & 0.034 & 0.148 & 0.144 & 0.004 \\
\hline & & & Mean & -57.9 & 4.3 & 18.2 & 305 & 10.1 & 0.877 & 0.872 & 0.030 & 0.098 & 0.092 & 0.006 \\
\hline & & $(\mathrm{N}=4)$ & $\operatorname{Max}$ & -56.9 & 5.1 & 22.5 & 326 & 10.0 & 0.940 & 0.902 & 0.031 & 0.154 & 0.151 & 0.003 \\
\hline & & & Mean & -57.5 & 4.8 & 20.3 & 318 & 9.4 & 0.856 & 0.866 & 0.028 & 0.107 & 0.103 & 0.004 \\
\hline \multirow[t]{27}{*}{ Group 3} & Group 3-1 & M & Min & -73.1 & -11.0 & 0.3 & 324 & 23.0 & & & & & & \\
\hline & & $(\mathrm{N}=4)$ & $\operatorname{Max}$ & -68.4 & -8.3 & 8.9 & 347 & 25.0 & & & & & & \\
\hline & & & Mean & -70.7 & -9.8 & 4.3 & 335 & 24.1 & & & & & & \\
\hline & & $(\mathrm{N}=3)$ & $\operatorname{Max}$ & -57.9 & 5.8 & 19.6 & 335 & 9.2 & 0.924 & 0.906 & 0.027 & 0.119 & 0.112 & 0.007 \\
\hline & & & Mean & -59.2 & 5.2 & 16.4 & 320 & 8.8 & 0.876 & 0.878 & 0.026 & 0.096 & 0.084 & 0.012 \\
\hline & Group 3-2 & $M$ & Min & -72.4 & -8.2 & 2.1 & 341 & 21.7 & & & & & & \\
\hline & & $(\mathrm{N}=3)$ & $\operatorname{Max}$ & -70.6 & -6.6 & 7.6 & 364 & 23.0 & & & & & & \\
\hline & & & Mean & -71.5 & -7.5 & 5.0 & 355 & 22.4 & & & & & & \\
\hline & & $\mathrm{C} 1$ & Min & -59.5 & 5.3 & 16.7 & 329 & 7.0 & 0.732 & 0.807 & 0.019 & 0.053 & 0.046 & 0.007 \\
\hline & & $(\mathrm{N}=3)$ & Max & -57.3 & 6.3 & 19.3 & 342 & 8.6 & 0.968 & 0.920 & 0.027 & 0.174 & 0.169 & 0.005 \\
\hline & & & Mean & -58.1 & 5.9 & 18.1 & 335 & 7.6 & 0.833 & 0.862 & 0.022 & 0.116 & 0.108 & 0.008 \\
\hline & Group 3-3 & $M$ & Min & -67.2 & -4.3 & 14.8 & 315 & 18.6 & & & & & & \\
\hline & & $(\mathrm{N}=3)$ & $\operatorname{Max}$ & -63.8 & -2.9 & 17.9 & 339 & 19.8 & & & & & & \\
\hline & & $(\mathrm{N}=4)$ & $\operatorname{Max}$ & -57.0 & 4.8 & 24.0 & 345 & 11.3 & 0.909 & 0.881 & 0.035 & 0.181 & 0.177 & 0.004 \\
\hline & & & Mean & -57.6 & 4.1 & 23.3 & 337 & 10.4 & 0.825 & 0.845 & 0.030 & 0.125 & 0.120 & 0.005 \\
\hline & Group 3-4 & $M$ & Min & -65.7 & -6.8 & 12.7 & 273 & 20.6 & & & & & & \\
\hline & & $(\mathrm{N}=4)$ & $\operatorname{Max}$ & -62.1 & -5.2 & 13.9 & 306 & 21.9 & & & & & & \\
\hline & & & Mean & -64.0 & -5.9 & 13.3 & 288 & 21.2 & & & & & & \\
\hline & & $C 1$ & Min & -57.9 & 3.8 & 19.7 & 282 & 9.8 & 0.847 & 0.859 & 0.029 & 0.055 & 0.052 & 0.003 \\
\hline & & $(\mathrm{N}=3)$ & $\operatorname{Max}$ & -56.8 & 4.5 & 22.0 & 297 & 10.9 & 0.973 & 0.911 & 0.034 & 0.112 & 0.111 & 0.001 \\
\hline & & & Mean & -57.2 & 4.2 & 20.9 & 290 & 10.3 & 0.925 & 0.894 & 0.032 & 0.075 & 0.073 & 0.002 \\
\hline & Group 3-5 & $M$ & Min & -73.1 & -6.2 & 8.8 & 325 & 20.4 & & & & & & \\
\hline & & $(\mathrm{N}=3)$ & $\operatorname{Max}$ & -71.2 & -4.9 & 13.7 & 346 & 21.4 & & & & & & \\
\hline & & & Mean & -72.0 & -5.5 & 11.2 & 336 & 20.9 & & & & & & \\
\hline & & C1 & Min & -61.4 & 2.9 & 17.4 & 320 & 10.6 & 0.802 & 0.831 & 0.030 & 0.047 & 0.037 & 0.010 \\
\hline & & $(\mathrm{N}=2)$ & $\operatorname{Max}$ & -59.8 & 4.0 & 21.6 & 338 & 12.1 & 0.999 & 0.914 & 0.039 & 0.139 & 0.120 & 0.019 \\
\hline & & & Mean & -60.6 & 3.5 & 19.5 & 329 & 11.3 & 0.895 & 0.874 & 0.034 & 0.092 & 0.075 & 0.017 \\
\hline
\end{tabular}


Table 3. Cont.

\begin{tabular}{|c|c|c|c|c|c|c|c|c|c|c|c|c|c|c|}
\hline FIA Group & FIA No. & FI Type & Range & $\mathrm{T}_{\mathrm{m} \text { carbon }}\left({ }^{\circ} \mathrm{C}\right)$ & $\mathrm{T}_{\mathrm{m} \text { clath }}\left({ }^{\circ} \mathrm{C}\right)$ & $\mathrm{T}_{\mathrm{h} \text { carbon }}\left({ }^{\circ} \mathrm{C}\right)$ & $\mathrm{T}_{\mathrm{h} \text { тот }}\left({ }^{\circ} \mathrm{C}\right)$ & $\begin{array}{c}\text { Salinity } \\
\text { (wt.\% NaCl) }\end{array}$ & $\begin{array}{c}\text { Bulk Density } \\
\left(\mathrm{g} / \mathrm{cm}^{3}\right)\end{array}$ & $\mathrm{XH}_{2} \mathrm{O}$ & $\mathrm{XNaCl}$ & $\begin{array}{c}\mathrm{XCO}_{2}+ \\
\mathrm{XCH}_{4}\end{array}$ & $\mathrm{XCO}_{2}$ & $\mathrm{XCH}_{4}$ \\
\hline & \multirow{6}{*}{ Group 3-6 } & $M$ & Min & -68.9 & -4.8 & 6.4 & 304 & 18.8 & & & & & & \\
\hline & & $(\mathrm{N}=4)$ & Max & -64.7 & -3.1 & 9.2 & 342 & 20.3 & & & & & & \\
\hline & & & Mean & -66.6 & -4.1 & 7.9 & 323 & 19.7 & & & & & & \\
\hline & & C1 & Min & -58.8 & 4.4 & 16.3 & 311 & 8.5 & 0.752 & 0.812 & 0.023 & 0.065 & 0.059 & 0.007 \\
\hline & & $(\mathrm{N}=3)$ & $\operatorname{Max}$ & -57.2 & 5.4 & 20.8 & 334 & 10.0 & 0.946 & 0.904 & 0.031 & 0.165 & 0.160 & 0.005 \\
\hline & & & Mean & -58.1 & 4.9 & 18.8 & 322 & 9.2 & 0.853 & 0.865 & 0.027 & 0.108 & 0.100 & 0.008 \\
\hline
\end{tabular}

Table 4. Summary of the microthermometric data and calculated parameters for Groups 4 and 5 FIAs from stage III quartz.

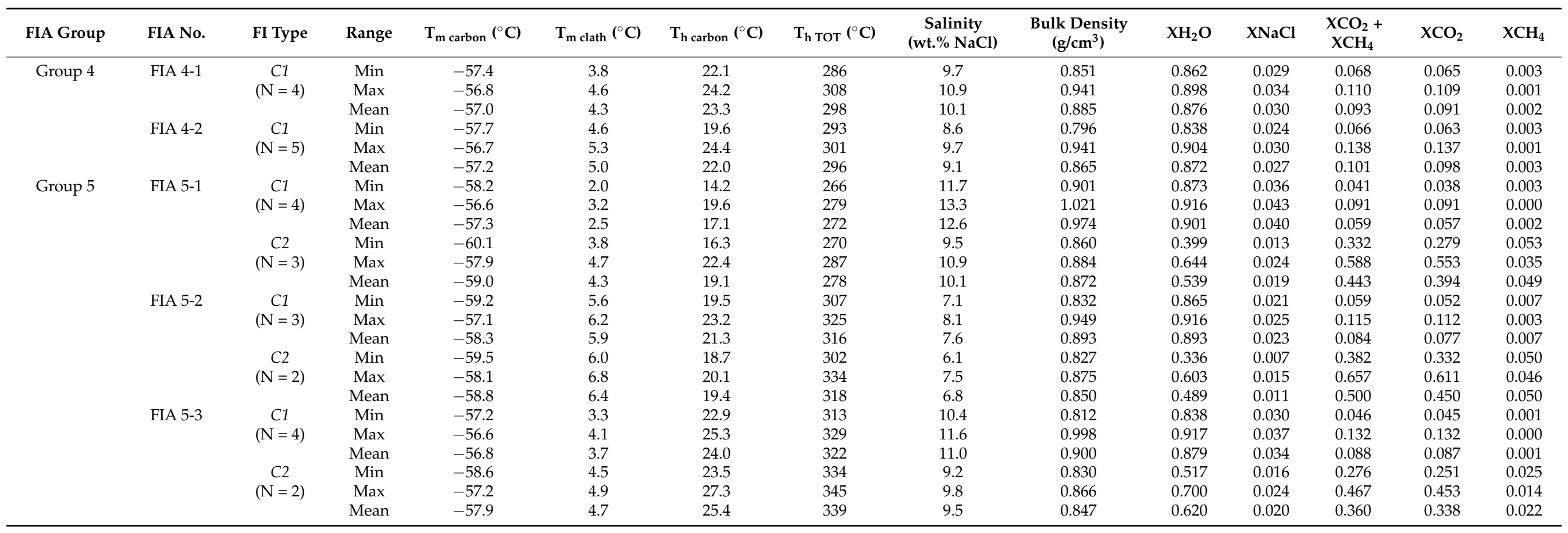


Table 4. Cont.

\begin{tabular}{|c|c|c|c|c|c|c|c|c|c|c|c|c|c|c|}
\hline FIA Group & FIA No. & FI Type & Range & $\mathrm{T}_{\mathrm{m} \text { carbon }}\left({ }^{\circ} \mathrm{C}\right)$ & $\mathrm{T}_{\mathrm{m} \text { clath }}\left({ }^{\circ} \mathrm{C}\right)$ & $\mathrm{T}_{\mathrm{h} \text { carbon }}\left({ }^{\circ} \mathrm{C}\right)$ & $\mathrm{T}_{\mathrm{h} \text { тот }}\left({ }^{\circ} \mathrm{C}\right)$ & $\begin{array}{c}\text { Salinity } \\
\text { (wt.\% NaCl) }\end{array}$ & $\begin{array}{l}\text { Bulk Density } \\
\left(\mathrm{g} / \mathrm{cm}^{3}\right)\end{array}$ & $\mathrm{XH}_{2} \mathrm{O}$ & $\mathrm{XNaCl}$ & $\underset{\mathrm{XCO}_{2}+}{\mathrm{XCH}_{4}}$ & $\mathrm{XCO}_{2}$ & $\mathrm{XCH}_{4}$ \\
\hline & \multirow[t]{5}{*}{ FIA 5-4 } & C1 & Min & -59.2 & 2.9 & 14.5 & 278 & 9.5 & 0.888 & 0.879 & 0.029 & 0.038 & 0.033 & 0.005 \\
\hline & & $(\mathrm{N}=4)$ & $\operatorname{Max}$ & -58.4 & 4.7 & 19.2 & 299 & 12.1 & 1.022 & 0.923 & 0.039 & 0.092 & 0.085 & 0.007 \\
\hline & & & Mean & -58.8 & 3.6 & 16.9 & 290 & 11.2 & 0.950 & 0.899 & 0.035 & 0.066 & 0.059 & 0.007 \\
\hline & & $(\mathrm{N}=2)$ & $\operatorname{Max}$ & -59.2 & 5.7 & 20.3 & 294 & 10.4 & 0.863 & 0.536 & 0.019 & 0.589 & 0.518 & 0.071 \\
\hline & & & Mean & -59.3 & 4.9 & 18.3 & 288 & 9.2 & 0.860 & 0.474 & 0.015 & 0.511 & 0.450 & 0.061 \\
\hline & \multirow[t]{5}{*}{ FIA 5-5 } & C1 & Min & -58.4 & 3.8 & 21.2 & 301 & 10.0 & 0.806 & 0.837 & 0.029 & 0.065 & 0.060 & 0.005 \\
\hline & & $(\mathrm{N}=2)$ & $\operatorname{Max}$ & -57.2 & 4.4 & 24.8 & 313 & 10.9 & 0.949 & 0.901 & 0.034 & 0.135 & 0.131 & 0.004 \\
\hline & & & Mean & -57.8 & 4.1 & 23.0 & 307 & 10.4 & 0.886 & 0.875 & 0.031 & 0.093 & 0.088 & 0.005 \\
\hline & & $(\mathrm{N}=3)$ & Max & -57.1 & 4.3 & 25.9 & 324 & 11.2 & 0.841 & 0.601 & 0.023 & 0.498 & 0.483 & 0.015 \\
\hline & & & Mean & -59.1 & 4.0 & 24.2 & 316 & 10.6 & 0.836 & 0.548 & 0.020 & 0.432 & 0.384 & 0.048 \\
\hline & \multirow[t]{6}{*}{ FIA 5-6 } & $\mathrm{C} 1$ & Min & -57.5 & 4.3 & 21.1 & 273 & 8.6 & 0.843 & 0.863 & 0.025 & 0.041 & 0.039 & 0.002 \\
\hline & & $(\mathrm{N}=4)$ & $\operatorname{Max}$ & -57.0 & 5.3 & 24.9 & 295 & 10.1 & 1.003 & 0.927 & 0.032 & 0.112 & 0.110 & 0.002 \\
\hline & & & Mean & -57.3 & 4.9 & 23.2 & 284 & 9.2 & 0.927 & 0.900 & 0.028 & 0.071 & 0.069 & 0.002 \\
\hline & & C2 & Min & -58.7 & 4.2 & 20.8 & 282 & 8.0 & 0.798 & 0.248 & 0.007 & 0.484 & 0.440 & 0.044 \\
\hline & & $(\mathrm{N}=3)$ & Max & -57.1 & 5.7 & 25.7 & 293 & 10.3 & 0.807 & 0.499 & 0.018 & 0.745 & 0.723 & 0.022 \\
\hline & & & Mean & -57.8 & 5.0 & 23.7 & 287 & 9.1 & 0.802 & 0.396 & 0.012 & 0.592 & 0.562 & 0.030 \\
\hline
\end{tabular}


Table 5. Summary of the microthermometric data and calculated parameters for Group 6 FIAs from stage IV quartz.

\begin{tabular}{|c|c|c|c|c|c|c|c|c|c|}
\hline $\begin{array}{c}\text { FIA } \\
\text { Group }\end{array}$ & FIA No. & FI Type & Range & $\begin{array}{c}\mathrm{T}_{\mathrm{h} \text { тот }} \\
\left({ }^{\circ} \mathrm{C}\right)\end{array}$ & $\begin{array}{c}\mathrm{T}_{\mathrm{m} \text { ice }} \\
\left({ }^{\circ} \mathrm{C}\right)\end{array}$ & $\begin{array}{c}\text { Salinity } \\
\text { (wt. } \% \mathrm{NaCl} \text { ) }\end{array}$ & $\begin{array}{l}\text { Bulk Density } \\
\left(\mathrm{g} / \mathrm{cm}^{3}\right)\end{array}$ & $\mathrm{XH}_{2} \mathrm{O}$ & $\mathrm{XNaCl}$ \\
\hline \multirow[t]{9}{*}{ Group 6} & Group 6-1 & $W$ & Min & 227 & -12.4 & 13.2 & 0.938 & 0.955 & 0.045 \\
\hline & & $(\mathrm{N}=4)$ & Max & 243 & -9.3 & 16.4 & 0.949 & 0.943 & 0.057 \\
\hline & & & Mean & 235 & -10.8 & 14.8 & 0.943 & 0.949 & 0.051 \\
\hline & Group 6-2 & W & Min & 215 & -9.5 & 11.4 & 0.916 & 0.962 & 0.038 \\
\hline & & $(\mathrm{N}=5)$ & Max & 232 & -7.7 & 13.4 & 0.952 & 0.954 & 0.046 \\
\hline & & & Mean & 223 & -8.6 & 12.4 & 0.935 & 0.958 & 0.042 \\
\hline & Group 6-3 & W & Min & 184 & -15.8 & 17.4 & 0.994 & 0.939 & 0.061 \\
\hline & & $(\mathrm{N}=4)$ & Max & 206 & -13.4 & 19.5 & 1.032 & 0.931 & 0.069 \\
\hline & & & Mean & 196 & -14.5 & 18.4 & 1.012 & 0.936 & 0.064 \\
\hline
\end{tabular}
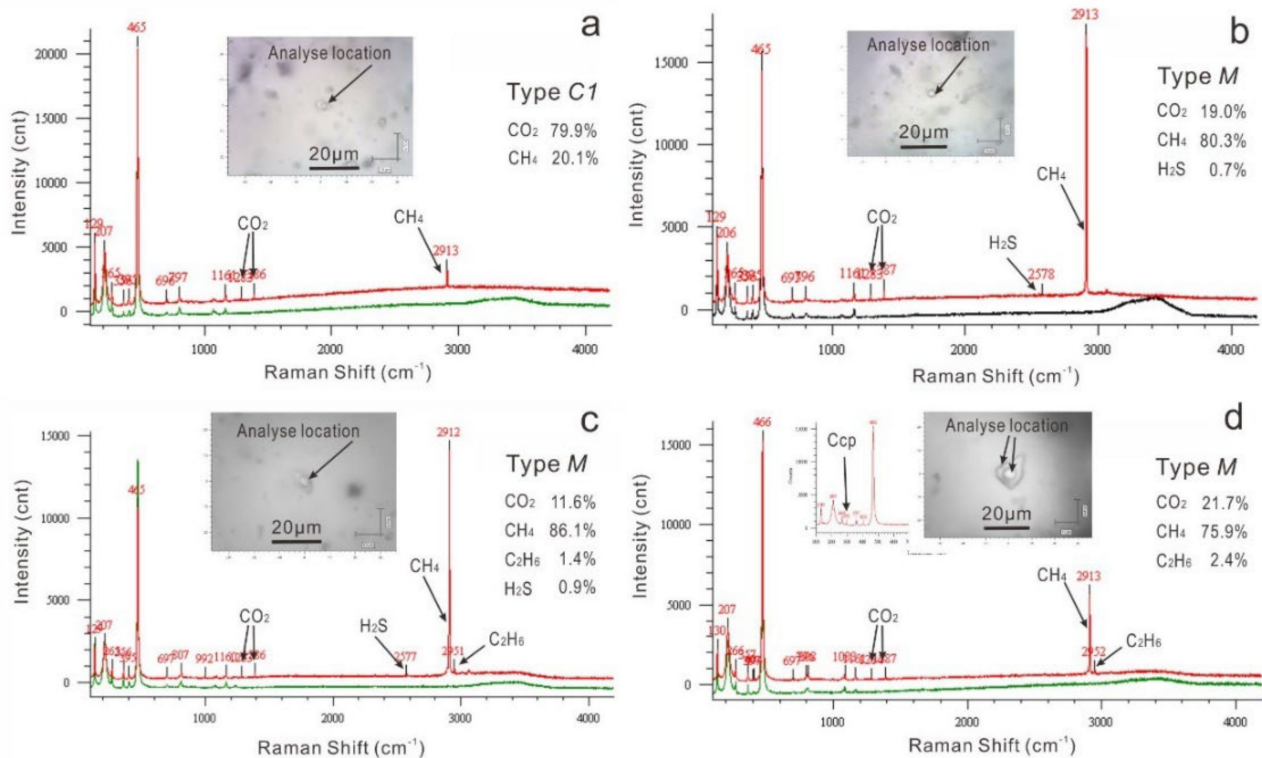

Figure 7. Laser Raman spectra of vapor bubbles (red color), aqueous (green color), or daughter minerals (in the $\mathbf{d}$ figure) of fluid inclusions in the Sanakham gold deposit. (a), Type C1 inclusion; (b-d), type $M$ inclusion.4.4. Composition and Density of Fluid Inclusions.

The salinity (wt\% $\mathrm{NaCl}$ equiv (eq.)), bulk density, and composition of the above fluid inclusions were estimated according to the program of Bakker [22] using the software MacFlincor [23]. The $\mathrm{CH}_{4}$ content in the carbonic phase of type $\mathrm{C}$ inclusions was estimated from the $\mathrm{V}-\mathrm{X}$ phase diagram of the $\mathrm{CO}_{2}-\mathrm{CH}_{4}$ system [24]. The bulk $\mathrm{CH}_{4}$ content, thus can be calculated combined with $\mathrm{X}_{\mathrm{CO} 2}+\mathrm{X}_{\mathrm{CH} 4}$ and carbonic $\mathrm{X}_{\mathrm{CH} 4}$. For the type $M$ inclusions, $\mathrm{CH}_{4}$ content is too high to get its accurate data based on the V-X phase diagram, thus evaluated by Laser Raman spectroscopy here. The salinities of type $M$ inclusions are calculated using $T_{\mathrm{m}}$ clath based on the equation from Darling et al. [25]. The bulk density of type $M$ inclusions are hard to assess because of the high $\mathrm{CH}_{4}$ content. The results of FIA assessment and math statistics are presented in Tables 2-5 and Figures 6 and 8. 


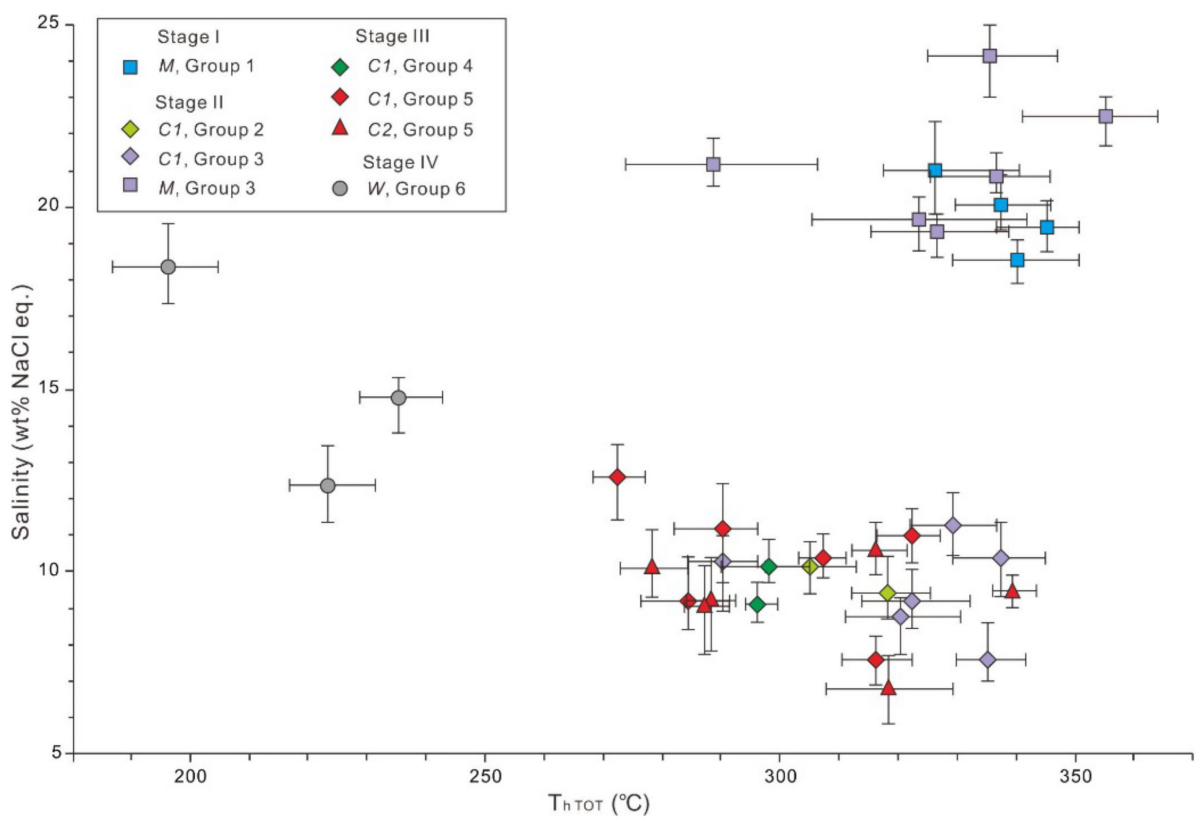

Figure 8. Homogenization temperature $\left(T_{\mathrm{h}}\right.$ тот) versus salinity ( $\mathrm{wt} \% \mathrm{NaCl}$ eq.) diagram showing the evolution of the ore-forming fluids for different groups of FIA from stages II and III quartz in the Sanakham gold deposit. The horizontal and vertical bars are the ranges of $T_{\mathrm{h}}$ TOT and salinity of every single FIA.

\subsubsection{Salinity}

Stage I: Salinities in type $M$ inclusions in Group 1 FIA vary from 18.6 to $21.0 \mathrm{wt} \% \mathrm{NaCl}$ eq. (mean $9.8 \mathrm{wt} \% \mathrm{NaCl}$ eq.).

Stage II: Salinities in type $C 1$ inclusions in Group 2 FIA vary from 9.4 to $10.1 \mathrm{wt} \%$ $\mathrm{NaCl}$ eq. (mean $9.8 \mathrm{wt} \% \mathrm{NaCl}$ eq.). The type $\mathrm{C} 1$ inclusions in Group 3 FIA that coexist with type $M$ inclusions, similarly, have salinities ranging from 7.6 to $11.3 \mathrm{wt} \% \mathrm{NaCl}$ eq. (mean $9.6 \mathrm{wt} \% \mathrm{NaCl}$ eq.). Type $M$ inclusions in Group 3 FIA, however, have higher salinities ranging from 19.3 to $24.1 \mathrm{wt} \% \mathrm{NaCl}$ eq. (mean $21.3 \mathrm{wt} \% \mathrm{NaCl}$ eq.), which are even higher than those in type $M$ inclusions in Group 1 FIA.

Stage III: The range of salinities of types $C 1$ and $C 2$ inclusions in Group 5 FIAs are 6.8-10.6 $\mathrm{wt} \%$ and $7.6-12.6 \mathrm{wt} \% \mathrm{NaCl}$ eq. (mean 10.3, and $9.2 \mathrm{wt} \% \mathrm{NaCl}$ eq.), respectively. The salinities of inclusions show a decreasing trend along with the increasing of $\mathrm{CO}_{2}$ content in Group 5 FIAs. Salinities of type $C 1$ inclusions in Group 4 FIA are 9.1-10.1 NaCl eq. (mean $9.6 \mathrm{wt} \% \mathrm{NaCl}$ eq.), basically equal to $\mathrm{C} 1$ inclusions in Group 5 FIA in stage III, as well as $C 1$ inclusions in Group 2 FIA in stage II.

Stage IV: Type $W$ inclusions in Group 6 FIA have relatively higher salinities of 12.4-18.4 $\mathrm{NaCl}$ eq. (mean $15.2 \mathrm{wt} \% \mathrm{NaCl}$ eq.) than $\mathrm{C} 1$ inclusions from previous stages.

\subsubsection{Bulk Density}

Stage II: The bulk densities of the type $C 1$ inclusions in both Groups 2 and 3 FIA are nearly the same, from $0.856-0.877 \mathrm{~g} / \mathrm{cm}^{3}\left(\right.$ mean $\left.0.867 \mathrm{~g} / \mathrm{cm}^{3}\right)$ and $0.825-0.925 \mathrm{~g} / \mathrm{cm}^{3}$ (mean $\left.0.868 \mathrm{~g} / \mathrm{cm}^{3}\right)$, respectively.

Stage III: For Group 5 FIA, the bulk densities of the type $C 1$ and $C 2$ inclusions are quite different, with ranges of $0.886-0.974 \mathrm{~g} / \mathrm{cm}^{3}\left(\right.$ mean $0.922 \mathrm{~g} / \mathrm{cm}^{3}$ ) and $0.802-0.872 \mathrm{~g} / \mathrm{cm}^{3}$ (mean $0.845 \mathrm{~g} / \mathrm{cm}^{3}$ ), respectively. Nevertheless, bulk densities of type $C 1$ inclusions in Group 4 FIA are $0.865-0.885 \mathrm{~g} / \mathrm{cm}^{3}$ (mean $0.875 \mathrm{~g} / \mathrm{cm}^{3}$ ), lower than the $C 1$ inclusions in Group 5 FIA in stage III but generally equal to $C 1$ inclusions in Group 2 FIA in stage II.

Stage IV: Bulk densities of $W$ inclusions in Group 6 FIA are $0.935-1.012 \mathrm{~g} / \mathrm{cm}^{3}$ (mean $0.963 \mathrm{~g} / \mathrm{cm}^{3}$ ), obviously higher than the type $C$ inclusions from the quartz of previous stages. 


\subsubsection{Content of $\mathrm{CO}_{2}$ and $\mathrm{CH}_{4}$}

Both type $M$ and $C$ inclusions are able to assume the contents of $\mathrm{CO}_{2}$ and $\mathrm{CH}_{4}$. For type $M$ inclusions, the content of $\mathrm{CO}_{2}+\mathrm{CH}_{4}$ varies from 30 to $80 \mathrm{~mol} \%$, carbonic $\mathrm{X}_{\mathrm{CH} 4}$ of are generally $70-85$ mole $\%$ based on Raman data.

In stage II, the type $\mathrm{C} 1$ inclusions from Group 2 FIAs consist of $\sim 87 \mathrm{~mol} \% \mathrm{H}_{2} \mathrm{O}$ with $\mathrm{CO}_{2}+\mathrm{CH}_{4}$ varying from 9.8 to $10.7 \mathrm{~mol} \%$ (mean $10.3 \mathrm{~mol} \%$ ), while the type $\mathrm{C} 1$ inclusions from Group 3 FIA that coexist with type $M$ inclusions have similar bulk compositions, with a relatively wider $\mathrm{CO}_{2}+\mathrm{CH}_{4}$ range of 7.5-12.5 mol\% (mean $10.2 \mathrm{~mol} \%$ ). The carbonic $\mathrm{X}_{\mathrm{CH} 4}$ of type $C 1$ inclusions in Groups 2 and 3 FIAs are $4-6 \mathrm{~mol} \%$ and $3-18 \mathrm{~mol} \%$, respectively. The bulk $\mathrm{X}_{\mathrm{CH} 4}$ of type $\mathrm{C} 1$ inclusions in Groups 2 and 3 FIAs are therefore calculated to be $0.4-0.6 \mathrm{~mol} \%$ (median $0.5 \mathrm{~mol} \%$ ) and $0.2-1.7 \mathrm{~mol} \%$ (median $0.9 \mathrm{~mol} \%$ ), respectively.

In stage III, the $\mathrm{CO}_{2}+\mathrm{CH}_{4}$ in type $\mathrm{C} 1$ and $\mathrm{C} 2$ inclusions from Group 5 FIAs have ranges of $5.9-9.3 \mathrm{~mol} \%$ (median $7.7 \mathrm{~mol} \%$ ) and $36.0-59.2 \mathrm{~mol} \%$ (median $47.3 \mathrm{~mol} \%$ ), respectively. The carbonic $\mathrm{CH}_{4}$ and bulk $\mathrm{CH}_{4}$ of $\mathrm{C} 2$ inclusions are, respectively, $5-12 \mathrm{~mol} \%$ and 2.2-6.1 mol\%, higher than the coexisting $\mathrm{C} 1$ inclusions (1-10 $\mathrm{mol} \%$ and $0.1-0.7 \mathrm{~mol} \%$ ). Type $\mathrm{C} 1$ inclusions in the two Group 4 FIAs have a higher content of $\mathrm{CO}_{2}+\mathrm{CH}_{4}(9.3-10.1 \mathrm{~mol} \%)$ than those in Group 5 FIA.

\section{Discussion}

\subsection{Nature of Ore-Forming Fluids}

According to fluid-inclusion petrography, Laser Raman spectroscopy, and microthermometry studies, there are big differences in composition among each fluid inclusion type and FIA group. Each of the Group 1, 2, 4, and 6 FIAs comprise only one type of fluid inclusion, and they represent a homogeneous fluid (Table 1). Group 1 FIA, consists of type $M$ $\mathrm{CH}_{4}$-rich fluid inclusions and represents a $\mathrm{CH}_{4}$-rich $\mathrm{CH}_{4}-\mathrm{CO}_{2}-\mathrm{NaCl}-\mathrm{H}_{2} \mathrm{O}$ system in stage $\mathrm{I}$, is characterized by medium temperatures $\left(326-345^{\circ} \mathrm{C}\right)$ and is $\mathrm{CH}_{4}$-rich $(\sim 20-70 \% \mathrm{~mol})$. Group 2 and 4 FIAs consist of type $C 1$ inclusions in stages II and III, respectively, belong to a $\mathrm{NaCl}-\mathrm{H}_{2} \mathrm{O}-\mathrm{CO}_{2}-\mathrm{CH}_{4}$ system, with medium temperatures $\left(296-318^{\circ} \mathrm{C}\right)$ and medium salinity $\left(9.1-10.1 \mathrm{wt} \% \mathrm{NaCl}\right.$ eq.), and are $\mathrm{CO}_{2}$-rich $(\sim 10 \% \mathrm{~mol})$ with minor $\mathrm{CH}_{4}(\sim 5 \%$ in carbonic phase). While Group 6 FIAs in stage IV belong to a $\mathrm{NaCl}-\mathrm{H}_{2} \mathrm{O}$ system, which is characterized by medium-low temperatures $\left(196-239^{\circ} \mathrm{C}\right)$ and relatively higher salinity (12.4-18.4 $\mathrm{wt} \% \mathrm{NaCl}$ eq.). Thus, the ore-forming fluids of Sanakham gold deposit might primarily belong to a medium temperature $\mathrm{CH}_{4}$-rich $\mathrm{CH}_{4}-\mathrm{CO}_{2}-\mathrm{NaCl}-\mathrm{H}_{2} \mathrm{O}$ system, which evolved into a $\mathrm{NaCl}-\mathrm{H}_{2} \mathrm{O}-\mathrm{CO}_{2}-\mathrm{CH}_{4}$ system in the main ore stage, and finally transformed into a medium-low temperature, medium-high salinity $\mathrm{NaCl}-\mathrm{H}_{2} \mathrm{O}$ fluid.

\subsection{Fluid Immiscibility Processes}

As mentioned above, both Group 3 FIAs in stage II and Group 5 FIAs in stage III consist of fluid inclusions with significantly different composition. The coexistence of the $\mathrm{CH}_{4}$-rich and $\mathrm{CO}_{2}$-rich inclusions (Group 3 FIA) and $\mathrm{C1}$ and $\mathrm{C} 2$ inclusions with obviously different contents of $\mathrm{CO}_{2}$ (Group 5 FIA) can be explained by the following three processes [26]: (1) fluid immiscibility caused by phase separation of a homogeneous fluid; (2) fluid mixing caused by heterogeneous trapping of multi-source hydrothermal fluids; or (3) post-entrapment modification. In this study, undeformed hydrothermal quartz grains with euhedral to subhedral shape are preferentially selected for fluid inclusion analysis. The inclusions for microthermometry, moreover, have no evidence of necking down [27]. The post-entrapment modification process thus can be excluded in Sanakham.

Ramboz et al. [28] propose three lines of evidence which may indicate a fluid immiscibility process for the two contrasting types of inclusions: (i) the two types of inclusions must occur in the same regions and there must be good evidence of contemporaneous trapping; (ii) the two types of inclusions must have similar total homogenization temperature ranges, with one type of inclusion homogenizing to the aqueous phase, and the others homogenizing to the vapor phase; (iii) if one inclusion type decrepitates before homogenization, then the other type must behave similarly. With reference to the above 
principles, Group 5 FIA meets the criteria of fluid immiscibility, including (1) type C1 and C2 inclusions contemporaneously trapped in the same FIA (Figure 5k,1); (2) type C1 and C2 inclusions, respectively, homogenize to the aqueous phase (liquid) and $\mathrm{CO}_{2}$ vapor phase, and have a similar $T_{\mathrm{h} \text { TOт }}\left(272-322^{\circ} \mathrm{C}\right.$ and $278-339^{\circ} \mathrm{C}$; Table 4$)$; (3) some coexisting $\mathrm{C} 1$ and $C 2$ inclusions generally have moderate $\mathrm{V} /(\mathrm{L}+\mathrm{V})$ ratios, decrepitate before homogenization, and are not recorded in the data sheet. In addition, type $\mathrm{C} 1$ inclusions have slightly higher salinities (7.6-12.6 wt\% $\mathrm{NaCl}$ eq.) than type $C 2$ inclusions (6.8-10.6 wt\% $\mathrm{NaCl}$ eq. Figure 7c), because salt is preferentially fractionated into the aqueous phase during phase separation [29]. It is inferred that the $C 1$ and $C 2$ inclusions in Group 5 FIA are two endmembers of unmixed fluids of a medium temperature, medium salinity, and $\mathrm{CO}_{2}$-rich parent fluid (Figure 9). Considering the widespread Group 5 FIA in stage III quartz, fluid immiscibility was a dominant process for stage III mineralization.

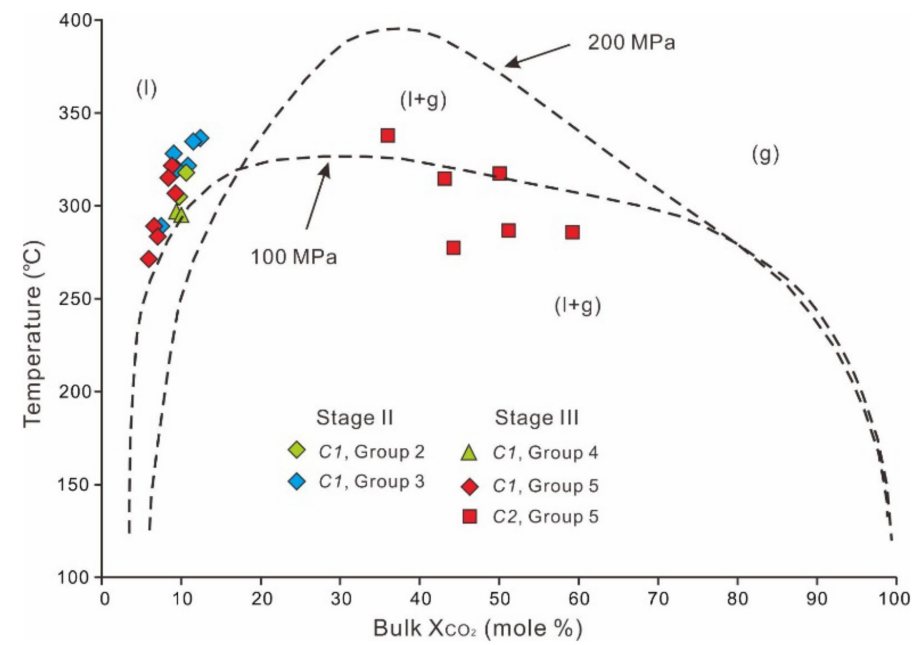

Figure 9. Homogenization temperature $\left(T_{\mathrm{h} \text { ТОT}}\right)$ versus calculated equivalent mole fraction $\mathrm{CO}_{2}$ of type $\mathrm{C} 1$ and $\mathrm{C} 2$ inclusions in stages II and III. The dashed curves delimit the two-phase regions of the $\mathrm{H}_{2} \mathrm{O}-\mathrm{CO}_{2}-\mathrm{NaCl}$ system at 100 and $200 \mathrm{MPa}$, respectively. Data after Bowers and Helgeson (1983) [30]. g, gas; l, liquid.

For Group 3 FIA in stage II quartz, the contemporaneously trapped type $M$ and $C 1$ inclusions also have similar homogenization temperature ranges (Figure $5 \mathrm{i}$ and Table 3), which are $288-355^{\circ} \mathrm{C}$ and $290-337^{\circ} \mathrm{C}$, respectively. Except for the liquid phase, furthermore, type $M$ and type $C 1$ inclusions have entirely different compositions in their carbonic phase. According to the Raman results, $\mathrm{CH}_{4}$ contents in the carbonic phase of type $M$ inclusions are $\sim 80 \%$, and the $\mathrm{CO}_{2}$ contents are $\sim 20 \%$. Meanwhile, the type $C$ inclusions contain contrary amounts of $\mathrm{CO}_{2}$ and $\mathrm{CH}_{4}$ (Figure 6), which can also be proven by their distinctly different $T_{\mathrm{m} \text { carbon }}$ (Table 3 ). Thus, we cannot attribute the Group 3 FIA to a heterogeneous trapping of multi-source fluids led by fluid mixing [31], which prefers a continuum of compositions in diverse fluid inclusions. The type $M$ and $C 1$ inclusions are better suggested to be two endmembers of unmixed fluids that belong to a $\mathrm{CH}_{4}$-rich $\mathrm{CH}_{4}-\mathrm{CO}_{2}-\mathrm{NaCl}-\mathrm{H}_{2} \mathrm{O}$ system. The fluid immiscibility process should also take part in stage II mineralization in Sanakham.

\subsection{Implications for Gold Deposition}

Given that the native gold in Sanakham is closely associated with sulfides such as pyrite, pyrrhotite, and chalcopyrite, the ore fluids are considered to be near-neutral to weakly acidic [32,33]. The ore-forming fluids are $<400^{\circ} \mathrm{C}$ and enriched in $\mathrm{CO}_{2}$, indicating that the gold-transporting species were probably bisulfide complexes, mainly $\mathrm{Au}(\mathrm{HS})^{2-}[34,35]$. Gold deposition, led by the destabilization of gold-bisulfide complexes, was likely associated with fluid immiscibility, fluid mixing, and other chemical changes [36,37]. 
Taking into consideration the fluid immiscibility process in stages II and III, the Group 3 and 5 FIAs are reliable for estimating the P-T conditions of gold mineralization. The final homogenization temperatures of type $\mathrm{C} 1$ inclusions, respectively, in Group 3 FIA $\left(290-337^{\circ} \mathrm{C}\right)$ and Group 5 FIA $\left(272-322^{\circ} \mathrm{C}\right)$ are considered to be close to the temperature of entrapment [20]. The P-T phase diagram (Figure 10) shows a representative solvus for $\mathrm{H}_{2} \mathrm{O}-$ $\mathrm{CO}_{2}$ fluids containing $10 \mathrm{wt} \% \mathrm{NaCl}$ eq. and $10 \mathrm{~mol} \% \mathrm{CO}_{2}$ (calculated after [30]), which is close to the composition of ore-forming fluids in stages II and III. The trapping pressures can be calculated from their isochores $\left(0.825-0.925 \mathrm{~g} / \mathrm{cm}^{3}\right.$ for stage II and $0.886-0.974 \mathrm{~g} / \mathrm{cm}^{3}$ for stage III) at the given homogenization temperatures. The estimated P-T conditions of gold mineralization in stages II and III ranged, respectively, from 134 to $65 \mathrm{MPa}$ and 337 to $290^{\circ} \mathrm{C}$, and 236 to $75 \mathrm{Mpa}$ and 322 to $272{ }^{\circ} \mathrm{C}$ (Figure 10). During fluid immiscibility caused by multiple hydraulic fracturing and pressure pulsation, gold deposition is believed to occur in conditions between lithostatic and hydrostatic pressure [38]. The highest and lowest pressures can be used to determine the depth considering that they are produced by the lithostatic and hydrostatic pressures, respectively. The densities of host quartz monzodiorite and ore-forming fluids are assumed, respectively, to be $2.7 \mathrm{~g} / \mathrm{cm}^{3}$ and $1.0 \mathrm{~g} / \mathrm{cm}^{3}$. Thus, for stage III, the calculated maximum and minimum depths are $8.7 \mathrm{~km}$ and $7.5 \mathrm{~km}$, respectively. However, the highest pressure (134 MPa) in stage II indicates a depth of $<5.0 \mathrm{~km}$, while the lowest pressure $(65 \mathrm{MPa})$ indicates a depth of $>6.5 \mathrm{~km}$. Taking the depth assumed from stage III into consideration, the depths for gold deposition in Sanakham are suggested to be 8.7-6.5 km. Fluid immiscibility in stage III occurred at relatively higher pressures than that in stage II, which might be attributed to a large release of $\mathrm{CO}_{2}$ and subsequent pressure increase in the fracture system.

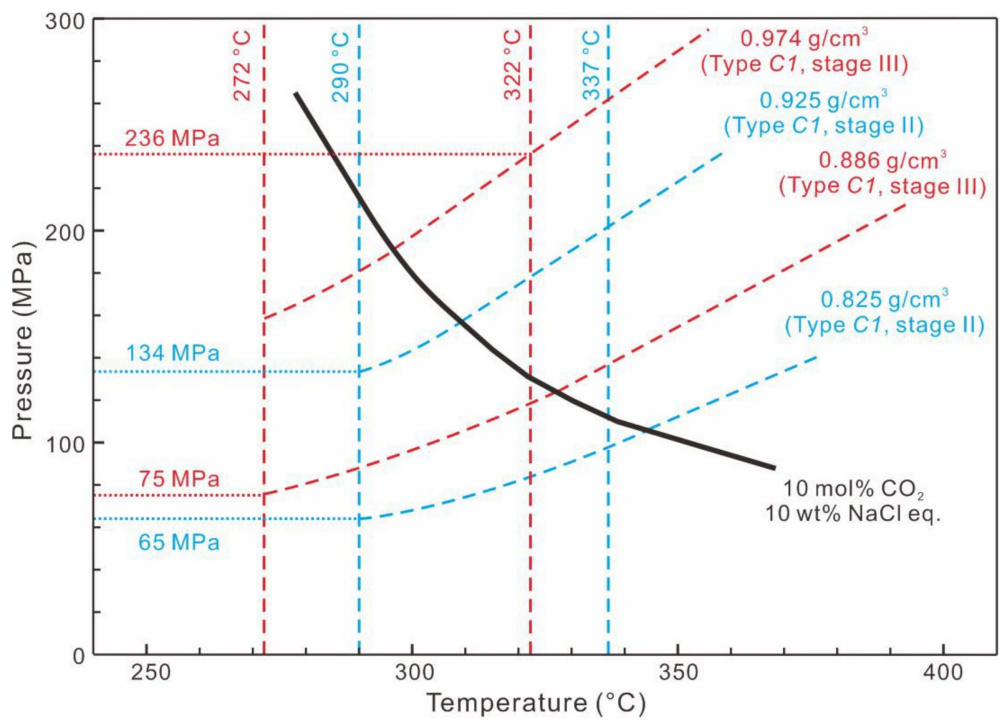

Figure 10. Estimated P-T conditions for the formation of the quartz veins in stages II and III in the Sanakham deposit. Representative isochores for mean bulk densities, respectively, for type $\mathrm{C} 1$ inclusions, and the solvus for $\mathrm{H}_{2} \mathrm{O}-\mathrm{CO}_{2}$ fluids containing $10 \mathrm{wt} \% \mathrm{NaCl}$ eq. and $10 \mathrm{~mol} \% \mathrm{CO}_{2}$ (calculated after reference [30]). The blue and red dashed lines define the range of $T_{\mathrm{h} \text { TOT }}$ and bulk density of type $C 1$ inclusions in Groups 3 and 5 FIA, respectively. The dotted lines represent the range of trapping pressures.

Except for Group 3 and 5 FIAs, which show evidence for fluid immiscibility, the homogenization temperatures of other primary fluid inclusions could only be regarded as the minimum temperature of entrapment. Combined with the above discussion, thus, the evolution of ore-forming fluids and related gold-deposition processes can be summarized below (as shown in Figure 11). The primary ore-forming fluids in stage I belonged to a $\mathrm{CH}_{4}$-rich $\mathrm{CH}_{4}-\mathrm{CO}_{2}-\mathrm{NaCl}-\mathrm{H}_{2} \mathrm{O}$ system (Group $1 \mathrm{FIA}$ ), which is characterized by mediumhigh temperature $\left(>345^{\circ} \mathrm{C}\right)$ and a high content of $\mathrm{CH}_{4}(\sim 20-70 \% \mathrm{~mol})$. The first fluid 
immiscibility process occurred in stage II and is represented by two coexisting endmembers (Group 3 FIA) including both those with high- $\mathrm{CH}_{4}$ and low- $\mathrm{CO}_{2}$ and the opposite. The ore fluids gradually evolved into a $\mathrm{NaCl}-\mathrm{H}_{2} \mathrm{O}-\mathrm{CO}_{2} \pm \mathrm{CH}_{4}$ fluid (Group 2 FIA) with medium temperature $\left(\sim 300^{\circ} \mathrm{C}\right)$, medium salinity $\left(9.1-10.1 \mathrm{wt} \% \mathrm{NaCl}\right.$ eq.), and a high content of $\mathrm{CO}_{2}$ $(\sim 10 \% \mathrm{~mol})$ during stages II and III. The second fluid immiscibility process occurred widely in stage III and therefore created two new coexisting endmembers (Group 5 FIA), which are the $\mathrm{CO}_{2}$-poor $(\sim 7 \% \mathrm{~mol})$ and relatively salinity-rich $(7.6-12.6 \mathrm{wt} \% \mathrm{NaCl}$ eq.) ones, as well as the opposite. Due to the volatile loss caused by fluid unmixing, the ore fluids finally evolved into a medium-low temperature $\left(>239^{\circ} \mathrm{C}\right)$, medium-high salinity $(12.4-18.4 \mathrm{wt} \%$ $\mathrm{NaCl}$ eq.) $\mathrm{NaCl}-\mathrm{H}_{2} \mathrm{O}$ system in stage IV (Group 6 FIA) accompanied by simply cooling. The two important gold-deposition events were generated, respectively, along with fluid immiscibility processes during stages II and III mineralization.

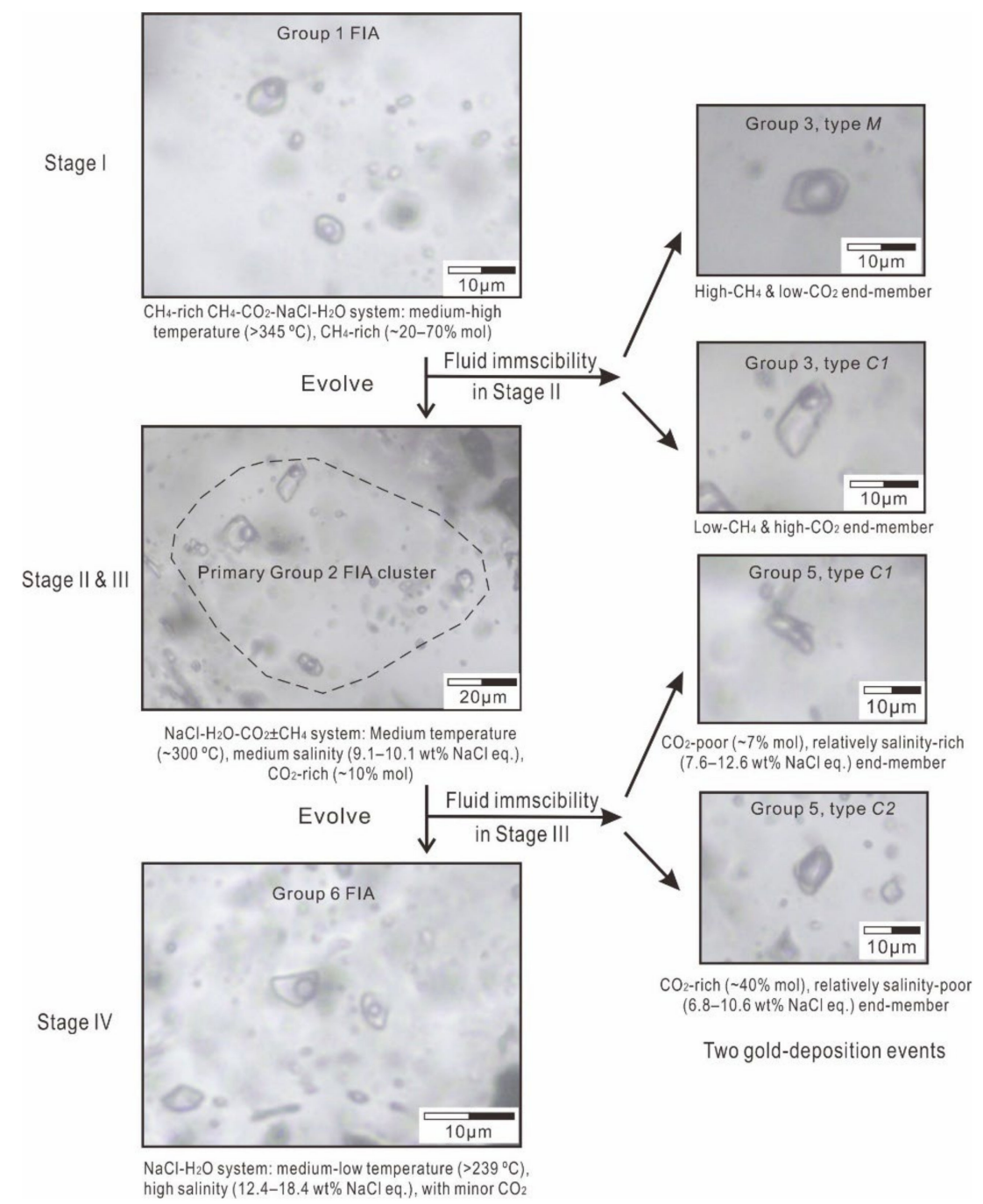

Figure 11. Evolution of ore-forming fluids and related gold-deposition processes in the Sanakham gold deposit.

Compared with important gold deposits in the Luang Prabang-Loei metallogenic belt, the epithermal gold class can be excluded in Sanakham because there is neither continental volcanic rock exposure, nor characteristic kaolinite, alunite, or porous silicification. Even though quartz monzodiorite predominates in the wall rock, the hydrothermal metasomatic alteration, such as skarnization and horny alteration, has little spatial relation with gold mineralization, different from the regional representative porphyry-skarn copper-gold deposits $[15,17]$. Actually, the lode-gold orebodies in Sanakham are strictly controlled 
by the NE-NNE trending faults and crosscut the lithological interfaces between quartz monzodiorite and slate (Figure 2), which is similar to the Phapon epizonal orogenic gold deposit in the northern part of the Luang Prabang-Loei belt $[13,14]$.

In most gold deposits, including porphyry and orogenic systems, the ore-forming fluids normally comprise remarkable contents of $\mathrm{CO}_{2}$ which are closely related to the fluid immiscibility system. Additionally, it is not uncommon for methane to be included in the ore fluids, e.g., gold deposits from Jiaodong [39-45], Ailaoshan [46], West Qinling [47,48], and Southwest Guizhou [49] in China, the Abitibi gold belt in Canada [50], and Hamadi gold deposit in Sudan [51], as well as some porphyry Cu-Mo and rare-metal deposits [52-61]. Based on high P-T experimental results, Naden et al. [62] pointed out that the $\mathrm{CH}_{4}$-bearing fluid system has a much wider immiscible area than the $\mathrm{CO}_{2}$-bearing fluid system under the same P-T conditions. At $300{ }^{\circ} \mathrm{C}$ for example, the immiscibility process could occur when $\mathrm{CO}_{2}$ content is higher than $15 \%$ mol, while the $\mathrm{CH}_{4}$ content only needs to be above $5 \%$ mol [63]. Thus, a small amount of $\mathrm{CH}_{4}$ in a $\mathrm{NaCl}-\mathrm{H}_{2} \mathrm{O}-\mathrm{CO}_{2}$ system could greatly expand the immiscibility area and result in gold deposition, which is identical to the stage II mineralization in Sanakham. However, the $\mathrm{CH}_{4}$-rich $\mathrm{CH}_{4}-\mathrm{CO}_{2}-\mathrm{NaCl}-\mathrm{H}_{2} \mathrm{O}$ ore fluids cannot be simply interpreted as products of alternative magmatic, metamorphic, or mantlederived fluids. It is generally assumed that the extremely high content of $\mathrm{CH}_{4}$ has an organic source, including partial decomposition of organic matter, or a reaction between water and graphite or organic carbon in the formations [64]. The Upper Carboniferous carbonaceous slate, therefore, might be a possible source of the abundant $\mathrm{CH}_{4}$, even though more refined studies on the source and evolution of ore-forming fluids are further needed.

\section{Conclusions}

The Sanakham gold deposit, located in the Luang Prabang-Loei metallogenic belt, predominately consists of auriferous quartz vein-type orebodies that are controlled by NE-NNE trending faults within Middle Triassic quartz monzodiorite and secondary Upper Carboniferous low-grade metamorphic rocks. Detailed study through petrography, microthermometry, and Laser Raman spectroscopy on fluid inclusions in gold-related quartz were carried out in the Sanakham gold deposit. The following conclusions are drawn from this study on the evolution of ore-forming fluids and gold deposition mechanisms in Sanakham:

(1) Four mineralization stages have been distinguished in Sanakham, of which the quartzpyrite-pyrrhotite-chalcopyrite stage (II) and the quartz-pyrite-base-metal sulfide stage (III) are identified as the main gold deposition stages.

(2) The initial ore-forming fluids belonged to a medium-high temperature $\mathrm{CH}_{4}$-rich $\mathrm{CH}_{4}-\mathrm{CO}_{2}-\mathrm{NaCl}-\mathrm{H}_{2} \mathrm{O}$ system, which gradually evolved into a medium temperature, medium salinity, and high $\mathrm{CO}_{2}$ content $\mathrm{NaCl}-\mathrm{H}_{2} \mathrm{O}-\mathrm{CO}_{2} \pm \mathrm{CH}_{4}$ system during the main ore stages, and then a medium-low temperature, medium-high salinity $\mathrm{NaCl}$ $\mathrm{H}_{2} \mathrm{O}$ system in stage IV.

(3) Gold-deposition events were generated along with the two fluid immiscibility processes during stage II and III mineralization, respectively. The former created two coexisting high- $\mathrm{CH}_{4}$ and low- $\mathrm{CO}_{2}$ and low- $-\mathrm{CH}_{4}$ and high- $\mathrm{CO}_{2}$ endmembers, while the latter created two coexisting $\mathrm{CO}_{2}$-poor and $\mathrm{CO}_{2}$-rich endmembers.

(4) The presence of $\mathrm{CH}_{4}$ in ore-forming fluids promoted the fluid immiscibility and resulted in gold deposition at $\mathrm{P}-\mathrm{T}$ conditions generally around 236 to $65 \mathrm{MPa}$ and 337 to $272{ }^{\circ} \mathrm{C}$, with estimated gold mineralization depths of $8.7-6.5 \mathrm{~km}$.

Author Contributions: Conceptualization, S.L. and L.G.; data curation, S.L., S.X. and H.L.; formal analysis, L.G. and J.D.; funding acquisition, S.L., L.G. and L.H.; investigation, L.G., M.S., F.N. and X.C.; writing—original draft, S.L.; writing—review and editing, L.G. and J.D. All authors have read and agreed to the published version of the manuscript.

Funding: This research was funded by the National Natural Science Foundation of China, grant No. 42102113; the China Geological Survey Project, grant No. DD20201161 and DD2019444; and the Open 
Research Fund from the Key Laboratory of Deep Geodynamics, Ministry of Natural Resources, grant No. J1901.

Data Availability Statement: Not applicable.

Acknowledgments: We thank the geologists from the Guanghang Mining Development Co., Ltd. in Laos for their assistance with the field work in the Sanakham gold deposit.

Conflicts of Interest: The authors declare that they have no known competing financial interests or personal relationships that could have appeared to influence the work reported in this paper.

\section{References}

1. Liu, S.S.; Yang, Y.F.; Guo, L.N.; Nie, F.; Peng, Z.M.; Pan, G.T. Tectonic characteristics and metallogeny in Southeast Asia. Geol. China 2018, 45, 863-889. (In Chinese with English abstract)

2. Goldfarb, R.J.; Taylor, R.D.; Collins, G.S.; Goryachev, N.A.; Orlandini, O.F. Phanerozoic continental growth and gold metallogeny of Asia. Gondwana Res. 2014, 25, 48-102. [CrossRef]

3. Khin, Z.; Meffre, S.; Lai, C.K.; Santosh, M.; Burrett, C.F.; Graham, I.T.; Manaka, T.; Salam, A.; Kamvong, T.; Cromie, P. Tectonics and metallogeny of mainland Southeast Asia-A review and contribution. Gondwana Res. 2014, 26, 5-30. [CrossRef]

4. Wang, Y.J.; Yang, T.X.; Zhang, Y.Z.; Qian, X.; Gan, C.S.; Wang, Y.K.; Wang, Y.; Vongpaseuth, S. Late Paleozoic back-arc basin in the Indochina block: Constraints from the mafic rocks in the Nan and Luang Prabang tectonic zones, Southeast Asia. J. Asian Earth Sci. 2020, 195, 104333. [CrossRef]

5. Shi, M.F.; Khin, Z.; Liu, S.S.; Xu, B.C.; Meffre, S.; Cong, F.; Nie, F.; Peng, Z.M.; Wu, Z.B. Geochronology and petrogenesis of Carboniferous and Triassic volcanic rocks in NW Laos: Implications for the tectonic evolution of the Loei Fold Belt. J. Asian Earth Sci. 2021, 208, 104661. [CrossRef]

6. Qian, X.; Feng, Q.L.; Yang, W.Q.; Wang, Y.J.; Chonglakmani, C.; Monjai, D. Arc-like volcanic rocks in NW Laos: Geochronological and geochemical constraints and their tectonic implications. J. Asian Earth Sci. 2015, 98, 342-357. [CrossRef]

7. Qian, X.; Feng, Q.L.; Wang, Y.J.; Chonglakmani, C.; Monjai, D. Geochronological and geochemical constraints on the mafic rocks along the Luang Prabang zone: Carboniferous back-arc setting in northwest Laos. Lithos 2016, 245, 60-75. [CrossRef]

8. Rossignol, C.; Bourquin, S.; Poujol, M.; Hallot, E.; Dabard, M.-P.; Nalpas, T. The volcaniclastic series from the Luang Prabang Basin, Laos: A witness of a Triassic magmatic arc? J. Asian Earth Sci. 2016, 12, 159-183. [CrossRef]

9. Shi, M.F.; Wu, Z.B.; Liu, S.S.; Peng, Z.M.; Guo, L.N.; Nie, F.; Xu, S.W. Geochronology and petrochemistry of volcanic rocks in the Xaignabouli area, NW Laos. J. Earth Sci. 2019, 30, 37-51. [CrossRef]

10. Guo, L.N.; Hou, L.; Nie, F.; Liu, S.S.; Xu, S.W.; Zhang, Q.M. Zircon U-Pb dating of quartz-diorite from Luang Prabang tectonic belt in Laos: Implication for eastward subduction of the Paleo-Tethys Ocean. Sediment. Geol. and Tethyan Geol. 2020, 40, 68-75, (In Chinese with English abstract).

11. Blanchard, S.; Rossignol, C.; Bourquin, S.; Dabard, M.P.; Hallot, E.; Nalpas, T.; Poujol, M.; Battail, B.; Jalil, N.E.; Steyer, J.S.; et al. Late Triassic volcanic activity in South-East Asia: New stratigraphical, geochronological and paleontological evidence from the Luang Prabang Basin (Laos). J. Asian Earth Sci. 2013, 70-71, 8-26. [CrossRef]

12. Qian, X.; Feng, Q.L.; Wang, Y.J.; Yang, W.Q.; Chonglakmani, C.; Monjai, D. Petrochemistry and Tectonic Setting of the Middle Triassic Arc-Like Volcanic Rocks in the Sayabouli Area, NW Laos. J. Earth Sci. 2016, 27, 365-377. [CrossRef]

13. Liu, S.S. Study on the Tectonics-Magmatic-Mineralization of the Luang Prabang-Loei Copper-Gold Metallogenic Belt. Ph.D. Thesis, Chengdu Univerisity of Technology, Chengdu, China, 2021.

14. Kamvong, T.; Khin, Z. The origin and evolution of skarn-forming fluids from the Phu Lon deposit, northern Loei Fold Belt, Thailand. Evidence from fluid inclusion and sulfur isotope studies. J. Asian Earth Sci. 2009, 34, 624-633. [CrossRef]

15. Nie, F.; Liu, S.S.; Yang, Y.F.; Peng, Z.M.; Guo, L.N. Zircon U-Pb dating of the diorite of Phu Lon skarn Cu-Au deposit in Thailand and its significance. Sediment. Geol. Tethyan Geol. 2019, 39, 71-78. (In Chinese with English abstract)

16. Salam, A.; Khin, Z.; Meffre, S.; McPhie, J.; Lai, C.K. Geochemistry and geochronology of epithermal Au-hosted Chatree volcanic sequence: Implication for tectonic setting of the Loei Fold Belt in central Thailand. Gondwana Res. 2014, 26, 198-217. [CrossRef]

17. Guo, L.N.; Hou, L.; Liu, S.S.; Nie, F. REE geochemistry and C-O isotope characteristics of hydrothermal calcites: Implications for fluid-rock reaction and ore-forming processes in the Phapon gold deposit, NW Laos. Minerals 2018, 8, 438. [CrossRef]

18. Guo, L.N.; Liu, S.S.; Hou, L.; Wang, J.T.; Zhang, Q.M.; Shi, M.F.; Nie, F.; Yang, Y.F.; Peng, Z.M. Fluid inclusion and C-H-O isotopes geochemistry of the Phapon gold deposit, NW Laos: Implications for fluid source and ore genesis. J. Earth Sci. 2019, 30, 80-94. [CrossRef]

19. Zhao, Y.P.; Kang, T.S.; Ning, G.C.; Ge, H.; Pan, H. Geochemical characteristics of the volcanic intrusive complex in the Pangkuam copper-gold deposit of Laos and its geological significance. Acta Petrol. Et Mineral. 2017, 36, 281-294. (In Chinese with English abstract)

20. Goldstein, R.H.; Reynolds, T.J. Systematics of Fluid Inclusions in Diagenetic Minerals; SEPM Short Course 31; SEPM Society for Sedimentary Geology: Tulsa, OK, USA, 1994; Volume 31, pp. 1-199.

21. Chi, G.X.; Diamond, L.W.; Lu, H.Z.; Lai, J.Q.; Chu, H.X. Common problems and pitfalls in fluid inclusion study: A review and discussion. Minerals 2021, 11, 7. [CrossRef] 
22. Bakker, R.J. Package Fluids 1. Computer programs for analysis of fluid inclusion data and for modelling bulk fluid properties. Chem. Geol. 2003, 194, 3-23. [CrossRef]

23. Brown, P.E.; Hagemann, S.G. MacFlincor and its application to fluids in Archaean lode-gold deposits. Geochim. Cosmochim. Acta 1995, 59, 3943-3952. [CrossRef]

24. Thiéry, R.; Vidal, J.; Dubessy, J. Phase equilibria modelling applied to fluid inclusions: Liquid-vapour equilibria and calculation of the molar volume in the $\mathrm{CO}_{2}-\mathrm{CH}_{4}-\mathrm{N}_{2}$ system. Geochim. Cosmochim. Acta 1994, 58, 1073-1082. [CrossRef]

25. Darling, R.S. An extended equation to calculate $\mathrm{NaCl}$ contents from final clathrate melting temperatures in $\mathrm{H}_{2} \mathrm{O}-\mathrm{CO}_{2}-\mathrm{NaCl}$ fluid inclusions: Implications for P-T isochore location. Geochim. Cosmochim. Acta 1991, 55, 3869-3871. [CrossRef]

26. Pichavant, M.; Ramboz, C.; Weisbrod, A. Fluid immiscibility in natural processes: Use and misuse: I. Phase equilibria analysis-a theoretical and geometrical approach. Chem. Geol. 1982, 37, 29-48.

27. Bakker, R.J.; Jansen, J.B.H. A mechanism for preferential $\mathrm{H}_{2} \mathrm{O}$ leakage from fluid inclusions in quartz, based on TEM observations. Contrib. Mineral. Petrol. 1994, 116, 7-20. [CrossRef]

28. Ramboz, C.; Pichavant, M.; Weisbrod, A. Fluid immiscibility in natural processes: Use and misuse of fluid inclusion data, II. Interpretation of fluid inclusion data in terms of immiscibility. Chem. Geol. 1982, 37, 29-48. [CrossRef]

29. Lawrence, D.M.; Treloar, P.J.; Rankin, A.H.; Boyce, A.; Harbidge, P. A fluid inclusion and stable isotope study at the Loulo mining district, Mali, West Africa: Implications for multifluid sources in the generation of orogenic gold deposits. Econ. Geol. 2013, 180, 229-257. [CrossRef]

30. Bowers, T.S.; Helgeson, H.C. Calculation of thermodynamic and geochemical consequences of nonideal mixing in the system $\mathrm{H}_{2} \mathrm{O}-\mathrm{CO}_{2}-\mathrm{NaCl}$ on phase relations in geologic systems: Equation of state for $\mathrm{H}_{2} \mathrm{O}-\mathrm{CO}_{2}-\mathrm{NaCl}$ fluids at high pressures and temperatures. Geochim. Cosmochim. Acta 1983, 47, 1247-1275. [CrossRef]

31. Anderson, M.R.; Rankin, A.H.; Spiro, B. Fluid mixing in the generation of mesothermal gold mineralization in the Transvaal Sequence, Transvaal, South Africa. Eur. J. Mineral. 1992, 4, 933-948. [CrossRef]

32. Williams-Jones, A.E.; Bowell, R.J.; Migdisov, A.A. Gold in solution. Elements 2009, 5, 281-287. [CrossRef]

33. Guo, L.N.; Goldfarb, R.J.; Wang, Z.L.; Li, R.H.; Chen, B.H.; Li, J.L. A comparison of Jiaojia- and Linglong-type gold deposit ore-forming fluids: Do they differ? Ore Geol. Rev. 2017, 88, 511-533. [CrossRef]

34. Benning, L.G.; Seward, T.M. Hydrosulphide complexing of gold (I) in hydrothermal solutions from 150 to $500^{\circ} \mathrm{C}$ and 500 to 1500 bars. Geochim. Cosmochim. Acta 1996, 60, 1849-1871. [CrossRef]

35. Phillips, G.N.; Evans, K.A. Role of $\mathrm{CO}_{2}$ in the formation of gold deposits. Nature 2004, 429, 860-863. [CrossRef] [PubMed]

36. Mikucki, E.J. Hydrothermal transport and depositional processes in Archean lode-gold systems: A review. Ore Geol. Rev. 1998, 13, 307-321. [CrossRef]

37. Pokrovski, G.S.; Tagirov, B.R.; Schott, J.; Hazemann, J.L.; Proux, O. A new view on gold speciation in sulfur-bearing hydrothermal fluids from in situ X-ray absorption spectroscopy and quantum-chemical modeling. Geochim. Cosmochim. Acta 2009, 73, 5406-5427. [CrossRef]

38. Weatherley, D.K.; Henley, R.W. Flash vaporization during earthquakes evidenced by gold deposits. Nat. Geosci. 2013, 6, $294-298$. [CrossRef]

39. Fan, H.R.; Zhai, M.G.; Xie, Y.H.; Yang, J.H. Ore-forming fluids associated with granite-hosted gold mineralization at the Sanshandao deposit, Jiaodong gold province, China. Mineral. Depos. 2003, 38, 739-750. [CrossRef]

40. Deng, J.; Yang, L.Q.; Groves, D.I.; Zhang, L.; Qiu, K.F.; Wang, Q.F. An integrated mineral system model for the gold deposits of the giant Jiaodong province, eastern China. Earth-Sci. Rev. 2020, 208, 103274. [CrossRef]

41. Deng, J.; Qiu, K.F.; Wang, Q.F.; Goldfarb, R.J.; Yang, L.Q.; Zi, J.W.; Geng, J.Z.; Ma, Y. In-situ dating of hydrothermal monazite and implications on the geodynamic controls of ore formation in the Jiaodong gold province, Eastern China. Econ. Geol. 2020, 115, 671-685. [CrossRef]

42. Goldfarb, R.J.; Mao, J.W.; Qiu, K.F.; Goryachev, N. The great Yanshanian metallogenic event of eastern Asia: Consequences from one hundred million years of plate margin geodynamics. Gondwana Res. 2021, 100, 223-250. [CrossRef]

43. Qiu, K.F.; Goldfarb, R.J.; Deng, J.; Yu, H.C.; Gou, Z.Y.; Ding, Z.J.; Wang, Z.K.; Li, D.P. Gold deposits of the Jiaodong Peninsula, eastern China. SEG Spec. Publ. 2020, 23, 753-773.

44. Guo, L.N.; Deng, J.; Yang, L.Q.; Wang, Z.L.; Wang, S.R.; Wei, Y.J.; Chen, B.H. Gold deposition and resource potential of the Linglong gold deposit, Jiaodong Peninsula: Geochemical comparison of ore fluids. Ore Geol. Rev. 2020, 120, 103434. [CrossRef]

45. Song, M.C.; Xue, G.Q.; Liu, H.B.; Li, Y.X.; He, C.Y.; Wang, H.J.; Wang, B.; Song, Y.X.; Li, S.Y. A Geological-Geophysical Prospecting Model for Deep-Seated Gold Deposits in the Jiaodong Peninsula, China. Minerals 2021, 11, 1393. [CrossRef]

46. Li, Y.; Wang, D.; Wang, C.; Sun, Y.; Pu-chi, M. Geology and Geochemistry of Selected Gold Deposits in the Ailaoshan Metallogenic Belt, China: Origin of Ore-Forming Fluids. Minerals 2021, 11, 1276. [CrossRef]

47. Qiu, K.F.; Yu, H.C.; Deng, J.; McIntire, D.; Gou, Z.Y.; Geng, J.Z.; Chang, Z.S.; Zhu, R.; Li, K.N.; Goldfarb, R.J. The giant Zaozigou orogenic Au-Sb deposit in West Qinling, China: Magmatic or metamorphic origin? Miner. Depos. 2020, 55, 345-362. [CrossRef]

48. Yang, L.Q.; Deng, J.; Dilek, Y.; Qiu, K.F.; Ji, X.Z.; Li, N.; Taylor, R.D.; Yu, J.Y. Structure, geochronology, and petrogenesis of the Late Triassic Puziba granitoid dikes in the Mianlue suture zone, Qinling Orogen, China. Geol. Soc. Am. Bull. 2015, 11/12, 1831-1854. [CrossRef] 
49. Peng, Y.W.; Gu, X.X.; Liu, L.; Cheng, W.B.; Zhang, Y.M.; Wu, C.Y.; Lv, P.R. Fluid inclusion characteristics and implications to mineralization in the Zimudang gold deposit in Southwest Guizhou Province, China. Acta Mineral. Sin. 2012, 32, 211-220, (In Chinese with English abstract).

50. Robert, F.; Kelly, W.C. Ore-forming fluids in Archean gold-bearing quartz veins at the Sigma Mine, Abitibi greenstone belt, Quebec, Canada. Econ. Geol. 1987, 82, 1464-1482. [CrossRef]

51. Xu, J.H.; Wang, J.X.; Xiang, P.; Li, Y.H.; Xiao, X.; Zhang, H.; Cheng, X.H. Extremely $\mathrm{CO}_{2}$-rich fluid inclusions in an orogenic gold deposit: Hamadi gold deposit of Sudan. Acta Petrol. Sin. 2015, 31, 1040-1048. (In Chinese with English abstract)

52. He, D.Y.; Qiu, K.F.; Santosh, M.; Yu, H.C.; Long, Z.Y.; Wang, J.Y. Inhomogeneous crust-mantle interaction and Triassic tectonic escape of a Proterozoic microplate: A tale of the Bikou Terrane. Lithos 2021, 396-397, 106227. [CrossRef]

53. Qiu, K.F.; Deng, J.; Yu, H.C.; Wu, M.Q.; Wang, Y.; Zhang, L.; Goldfarb, R. Identifying hydrothermal quartz vein generations in the Taiyangshan porphyry Cu-Mo deposit (West Qinling, China) using cathodoluminescence, trace element geochemistry, and fluid inclusions. Ore Geol. Rev. 2021, 128, 103882. [CrossRef]

54. Qiu, K.F.; Taylor, R.D.; Song, Y.H.; Yu, H.C.; Song, K.R.; Li, N. Geologic and geochemical insights into the formation of the Taiyangshan porphyry copper-molybdenum deposit, Western Qinling Orogenic Belt, China. Gondwana Res. 2016, 35 , 40-58. [CrossRef]

55. Wang, Y.; Qiu, K.F.; Müller, A.; Hou, Z.L.; Zhu, Z.H.; Yu, H.C. Machine Learning Prediction of Quartz Forming-Environments. J. Geophys. Resour. Solid Earth 2021, 126, e2021jb021925. [CrossRef]

56. Qiu, K.F.; Yu, H.C.; Hetherington, C.; Huang, Y.Q.; Yang, T.; Deng, J. Tourmaline composition and boron isotope signature as a tracer of magmatic-hydrothermal processes. Am. Miner. 2021, 106, 1033-1044. [CrossRef]

57. Qiu, K.F.; Yu, H.C.; Wu, M.Q.; Geng, J.Z.; Ge, X.K.; Gou, Z.Y.; Taylor, R.D. Discrete Zr and REE mineralization of the Baerzhe rare-metal deposit, China. Am. Miner. 2019, 104, 1487-1502. [CrossRef]

58. Wu, M.Q.; Samson, I.M.; Qiu, K.F.; Zhang, D.H. Concentration mechanisms of REE-Nb-Zr-Be mineralization in the Baerzhe deposit, NE China: Insights from textural and chemical features of amphibole and rare-metal minerals. Econ. Geol. 2021, 116, 651-679. [CrossRef]

59. Yu, H.C.; Qiu, K.F.; Hetherington, C.J.; Chew, D.; Huang, Y.Q.; He, D.Y.; Geng, J.Z.; Xian, H.Y. Apatite as an alternative petrochronometer to trace the evolution of magmatic systems containing metamict zircon. Contrib. Mineral. Petrol. 2021, 176, 68. [CrossRef]

60. Yu, H.C.; Qiu, K.F.; Pirajno, F.; Zhang, P.C.; Dong, W.Q. Revisiting Phanerozoic evolution of the Qinling Orogen (East Tethys) with perspectives of detrital zircon. Gondwana Res. 2021, accepted. [CrossRef]

61. Zhang, L.; Qiu, K.F.; Hou, Z.L.; Pirajno, F.; Shivute, E.; Cai, Y.W. Fluid-rock reactions of the Triassic Taiyangshan porphyry Cu-Mo deposit (West Qinling, China) constrained by QEMSCAN and iron isotope. Ore Geol. Revi. 2021, 132, 104068. [CrossRef]

62. Naden, J.; Shepherd, T.J. Role of methane and carbon dioxide in gold depositions. Nature 1989, 342, 793-795. [CrossRef]

63. Van den Kerkhof, A.M.; Thiéry, R. Carbonic inclusions. Lithos 2001, 55, 49-68. [CrossRef]

64. Jiang, N.; Wang, Y.L. The role of $\mathrm{CH}_{4}$ in gold mineralization. Global Geol. 1995, 14, 29-32. (In Chinese) 